\title{
Mg-Modified Sugarcane Bagasse Biochar for Dual Removal of Ammonium and Phosphate Ions from Aqueous Solutions
}

Maher E. Saleh ${ }^{1}$ and Ramzy M. R. Hedia ${ }^{1}$

\begin{abstract}
Utilization of agricultural wastes to generate cheap and efficient sorbents to remove contaminants from wastewaters is an up-to-date environmental challenge. In Egypt, sugarcane bagasse is yearly generated as a waste material in huge amounts. The objectives of this study were to investigate the effect of chemical modification on the properties of bagasse biochar generated from local sugarcane bagasse feedstock (SCBF) and assess its efficiency for removal of both ammonium and phosphate ions from artificial aqueous solutions. SCBB and MgSCBB biochars were produced through pyrolysis of raw $\mathrm{SCBF}$ and $\mathrm{MgSO}_{4}$ impregnated $\mathrm{SCBF}$, respectively at 500 $\mathrm{C}$ and under oxygen-limited condition. FTIR peaks analysis, DEM examination, and some physical and chemical properties revealed that new surface functional groups, meso- and micropores, larger surface area and higher CEC were developed in SCBB and Mg-SCBB compared to SCBF. SCBB and Mg-SCBB showed high affinity to ammonium adsorption from aqueous solutions comparable to Charcoal and Zeolite. Mg-SCBB was the only sorbent capable of removing phosphate from the aqueous. Ammonium and phosphate removal at 1:200 sorbent to solution ratio were higher than those at 1:500 for all sorbents. A slight ammonium volatilization occurred during the adsorption process due to high solution $\mathbf{p H}$. Adsorption kinetics data were best fitted to the pseudo-second-order kinetic equation suggesting intraparticle diffusion controlled adsorption process. Ammonium adsorption isotherms were best fitted to Freundlich model. The calculated Freundlich intensity parameter (n) ranged from 0.478 to 0.894 indicating favorable adsorption of ammonium and phosphate by all sorbents. Mg-SCBB had an adsorption capacity of 2573.9 and $4002.2 \mathrm{mg} \mathrm{kg}^{-1}$ for ammonium and phosphate, respectively. The produced Mg-modified sugarcane bagasse biochar may represent a promising efficient and cheap sorbent for dual remediation of wastewaters contaminated with ammonium and phosphate ions.
\end{abstract}

Keywords: Sugarcane bagasse, Mg-modified biochar, ammonium and phosphate removal, agricultural wastes, aqueous solutions.

\section{INTRODUCTION}

Due to fast industrialization and the widespread application of agrochemicals, the occurrence of organic and inorganic pollutants has considerably increased in our environment and food chain. Therefore, serious public and governmental concerns about the environmental pollution and human health have been raised (WHO, 2017). Due to inefficient management of agricultural fertilizers and large discharge of wastewaters, the concentrations of various nutrients $\left(\mathrm{NH}_{4}{ }^{+}, \mathrm{NO}_{3}{ }^{-}\right.$and $\left.\mathrm{PO}_{4}^{-3}\right)$ are largely increased in surface and groundwater resources globally (Carey et al., 2015). Freshwater containing elevated nutrients concentrations discharges into oceans depleting dissolved oxygen concentrations and promoting harmful algal blooms. This creates hypoxic 'dead zones' and causes ecological damage (Dunnivant and Anders, 2006).

Ammonium ion has a positive charge and a much lower charge-to-radius ratio than many metal cations. Therefore, $\mathrm{NH}_{4}{ }^{+}$is mainly attracted to the negatively charged surfaces of colloidal particles and behaves similarly to alkali metal cations (e.g. $\mathrm{Na}^{+}, \mathrm{K}^{+}$). Unlike divalent metal cations, $\mathrm{NH}_{4}{ }^{+}$does not form stable bonds with surfaces to which it is attached. However, the oxyanions $\mathrm{NO}_{3}^{-}$and $\mathrm{PO}_{4}^{-3}$ are negatively charged and thus attracted to positively charged surfaces. With different behavior to each other, $\mathrm{NO}_{3}{ }^{-}$is much more mobile while $\mathrm{PO}_{4}^{-3}$ is readily bound to surfaces of colloidal particles in water (Conley et al., 2009). Common methods of remediation polluted aqueous phases include ion exchange, precipitation, membrane separation and adsorption (using activated carbon) techniques among others. These techniques are expensive and produce chemical residues which have uneconomic value.

Biochar is a carbonaceous, fine-grained, porous solid material produced by pyrolysis of a wide variety of biomasses under different conditions. As a low-cost substitute of activated carbon, biochar can be used as carbon sequestration and soil amendment (Carey et al., 2015; Agegnehu et al., 2017). Besides, biochar is recently used as a green environmental sorbent to remove diverse organic contaminants such as aromatic dyes, antibiotics, polychlorinated biphenyls (PCBs), polycyclic aromatic hydrocarbons (PAHs), volatile organic compounds (VOCs) and agrochemicals from aqueous and gaseous phases (Qiu et al., 2009; Beesley et al., 2010; Zheng et al., 2010; Teixido et al., 2011; Xu et al., 2011; Saleh et al., 2016; De Jesus et al., 2017), or inorganic contaminants such as heavy metals and various nutritional elements $\left(\mathrm{NH}_{4}{ }^{+}, \mathrm{NO}_{3}{ }^{-}\right.$and $\left.\mathrm{PO}_{4}{ }^{-3}\right)$ from urban and industrial wastewaters and agricultural drainage water (Fang et al., 2014; Saleh et al., 2012;

${ }^{1}$ Soil \& Water Sciences Department, Faculty of Agriculture, Alexandria University

Received February 27, 2018, Accepted March 27, 2018 
Saleh et al., 2013; Hafshejani et al., 2016; Cai et al., 2017; Strock et al., 2017). Biochar has been recently used to improve agricultural ecosystems and reduce the emission of greenhouse gases (Ulyett et al., 2014; Tan et al., 2017). Biomass is converted to biochar by pyrolysis, a thermochemical process under oxygenlimited or anoxic conditions (Zhang et al., 2010). The conversion process includes drying and grinding of biomass, pyrolysis and then separation (Pan et al., 2010). Factors affecting the characteristics of generated biochar include the type of feedstock, reaction time and conditions of thermochemical conversion (Zhang et al., 2015; Li et al. 2016; Sizmur et al., 2017; Tan et al. 2017). While the alkaline nature of biochar is determined by the metal alkalinity content of ash, cation exchange capacity is related to the surface area, surface functional groups (mainly carboxyl groups), type of feedstock and temperature of pyrolysis (Jiang et al., 2013; Luo et al., 2015; El-Gamal et al., 2017).

Sugar production in Egypt is expected to reach 2.42 MMT (Million Metric Tons) in 2017/2018. About $42 \%$ of this production (1.02 MMT) is produced from sugarcane (FAS-USDA, 2017). Sugarcane is also a source of molasses. In this report, sugarcane cultivated area was forecasted to increase 10,000 ha to reach 119,000 ha in $2017 / 18$, mostly located in Upper Egypt. Bagasse, as the residue of sugarcane processing, is limitedly used in paper pulp and plywood industries. Therefore, a large amount of sugarcane bagasse is not economically utilized. Several attempts have been made to increase the value of sugarcane bagasse through conversion to biochar by pyrolysis (Hugo, 2010; Jeong et al., 2016). Sugarcane bagasse biochar (SCBB) was produced under various pyrolysis conditions (Ding et al., 2014; Cha et al., 2016; Huang et al., 2015; Li et al., 2016) including temperature (ranged from 250 to $<900$ ${ }^{\circ}$ C) which affects its porosity and specific surface area (SSA), heating facilities (traditional kilns, muffle furnace, or microwave oven), reaction time (ranged from $20 \mathrm{~min}$ to $8 \mathrm{~h}$ ) and atmosphere (oxygen-limited, vacuum or $\mathrm{N}_{2}$-saturated atmosphere). Sugarcane bagasse was used either in its raw state (Hugo, 2010; Ding et al., 2014; Jeong et al., 2016), anaerobically digested (Inyang et al., 2010), or subjected to different physical or chemical treatments to enhance its sorption capacity and/or selectivity (Hafshejani et al., 2016; Noraini et al., 2016; Schwantes et al., 2015).

The efficiency of SCBB was investigated to remove heavy metals such as cadmium, chromium, lead and mercury (Ding et al., 2014; Li et al., 2017; Noraini et al., 2016), organic dyes (Carrier et al., 2012), nitrate (Schwantes 2015; Hafshejani et al., 2016) and phosphate (Trazzi et al., 2016) from aqueous solutions or wastewaters.
Ding et al. (2014) found that SCBB produced at different pyrolysis temperatures (from 250 to $600{ }^{\circ} \mathrm{C}$ ) was effective in $\mathrm{Pb}^{2+}$ sorption from aqueous solutions and the sorption capacity of the produced biochar decreased with increasing the temperature of pyrolysis (from 2.1 to $6.1 \mathrm{mg} \mathrm{Pb} / \mathrm{g}$ biochar at 250 and $600{ }^{\circ} \mathrm{C}$, respectively). The initially, rapid $\mathrm{Pb}$ sorption was probably controlled by ion exchange and/or complexation then it was slowed down due to intraparticle diffusion. Noraini et al., (2016) reported that magnetic biochar produced from sugarcane bagasse by microwave heating at optimum conditions of $30 \mathrm{~min}$ of radiation time and $\mathrm{Fe}_{2} \mathrm{O}_{3}$ impregnation ratio 0.45 ( $\mathrm{Fe}_{2} \mathrm{O}_{3}$ : biomass), could enhance the removal efficiency of $\mathrm{Cd}^{2+}$ to $96.17 \%$ from aqueous solutions. Carrier et al. (2012) obtained a high-quality SCBB was also produced by vacuum pyrolysis and steam activation having an SSA of $418 \mathrm{~m}^{2} \mathrm{~g}^{-1}$ and a cation exchange capacity (CEC) of $122 \mathrm{cmol}_{\mathrm{c}} \mathrm{kg}^{-1}$. This biochar was very efficient in methylene blue (MB) adsorption and favored physisorption rather than chemisorption.

The efficiency of nitrate adsorption by SCBB, generated at $300{ }^{\circ} \mathrm{C}$ for $4 \mathrm{~h}$ in a carbonization furnace, was enhanced by chemical modification of air-dried bagasse using epichlorohydrin, dimethylformamide and ethylenediamine combination before pyrolysis (Hafshejani et al., 2016). Adsorption capacity for nitrate removal from aqueous solutions was increased from 11.56 to $28.21 \mathrm{mg} \mathrm{g}^{-1}$ for SCBB and modified SCBB, respectively. The maximum capacity $\left(\mathrm{q}_{\max }\right)$ of nitrate was reached with sorbent dose of $2 \mathrm{~g} \mathrm{~L}^{-1}$, equilibrium $\mathrm{pH} 4.64$ and after $60 \mathrm{~min}$ of contact time. Schwantes et al. (2015) showed that SCBB produced from $3 M$ $\mathrm{H}_{3} \mathrm{PO}_{4}$-activated bagasse was efficient in $\mathrm{NO}_{3}{ }^{-}$removal from aqueous solutions. The adsorption isotherms followed the Freundlich model and sorption kinetics data were fitted to the pseudo-second-order equation.

Trazzi et al. (2016) found that surface area and fixed carbon content of SCBB were increased with increasing pyrolysis temperature and residence time. The best performance was observed for SCBB formed at $500{ }^{\circ} \mathrm{C}$ for $60 \mathrm{~min}$. in terms of energy expended and phosphate sorption. Adsorption on of phosphate was found to be non-spontaneous, endothermic process and adsorption capacity increased with temperature.

Therefore, the objectives of this study were to investigate the effect of chemical modification on the properties of bagasse biochar generated from local sugarcane bagasse and to assess its efficiency for removal of both ammonium and phosphate ions from aqueous solutions. 


\section{MATERIALS AND METHODS \\ Preparation of feedstock:}

Sugarcane bagasse feedstock (SCBF) was collected from the local market in Alexandria Governorate. SCBF was cut into $2.0 \mathrm{~cm}$ segments, washed with tap water, then with distilled water and oven-dried at $70 \circ \mathrm{C}$ for 24 h. The oven-dried SCBF was left to cool to reach the ambient lab temperature and then stored in a plastic vessel for the pyrolysis step. A slight modification to the method outlined by Fang et al. (2014) was made to prepare $\mathrm{Mg}$-saturated SCBF. A portion of the ovendried SCBF was soaked in $1.6 \mathrm{M} \mathrm{MgSO}_{4} .7 \mathrm{H}_{2} \mathrm{O}$ at $1: 10$ solid to solution ratio for $2 \mathrm{~h}$. The $\mathrm{Mg}$-saturated $\mathrm{SCBF}$ (Mg-SCBF) was then oven-dried at $80{ }^{\circ} \mathrm{C}$ for $48 \mathrm{~h}$, left to cool to ambient temperature and stored in a plastic vessel for the pyrolysis step.

\section{Generation of biochar:}

Biochar was generated by heating SCBF and $\mathrm{Mg}$ SCBF under oxygen-limited condition (pyrolysis). For pyrolysis, $200 \mathrm{~g}$ of both previously prepared SCBF and $\mathrm{Mg}-\mathrm{SCBF}$ was tightly wrapped in an aluminum foil sheet. The wrappings were perforated with five tiny halls to allow pyrolytic gases to escape and facilitate an oxygen-limited condition. Pyrolysis was conducted in a muffle furnace by increasing temperature at a rate of 25 ${ }^{\circ} \mathrm{C} / \mathrm{min}$ to reach $500{ }^{\circ} \mathrm{C}$ and then heating was continued at $500{ }^{\circ} \mathrm{C}$ for $60 \mathrm{~min}$. The generated bagasse (SCBB) and the Mg-modified bagasse biochars (Mg-SCBB) were left to cool to room temperature and the produced carbonaceous material was weighed. Afterwards, biochars were ground in a porcelain mortar and pestle and sieved through $0.5 \mathrm{~mm}$ polyethylene sieve. The biochars were then washed several times with distilled water, oven-dried at $80{ }^{\circ} \mathrm{C}$ for $24 \mathrm{~h}$, left to cool to room temperature and finally stored in plastic vessels for subsequent experiments.

\section{Characterization of sorbents:}

Percent of biochar yield and volatile matter were calculated from the oven-dried SCBF and the generated carbonized materials after pyrolysis. The $\mathrm{pH}$ was measured ( $\mathrm{pH}$-meter, Inolab $\mathrm{pH} / \mathrm{Ion} 735$ ) in the suspensions of $1.0 \mathrm{~g}$ biochar in $100 \mathrm{ml}$ of distilled water. The electrical conductivity $\left(\mathrm{EC}, \mathrm{dS} \mathrm{m}^{-1}\right)$ was measured using a conductivity meter (WTW inoLab Cond $720, \mathrm{GmbH})$ in the filtrate of a $5 \% \mathrm{~W} / \mathrm{V}$ solid/distilled water suspension. Surface area $\left(\mathrm{m}^{2} \mathrm{~g}^{-1}\right)$ of the biochars was determined using the methylene blue method (Kaewprasit et al., 1998). The ash content of biochars was determined according to Samsuri et al. (2014) in open porcelain crucibles using the muffle furnace at $700 \circ \mathrm{C}$ for $12 \mathrm{hrs}$. Cation exchange capacity (CEC) was determined using the modified ammonium acetate compulsory displacement procedure (Gaskin et al., 2008). The CHNS Elemental Analyzer (Vario, type El) was utilized to determine the carbon, hydrogen, nitrogen, and sulfur contents.

Fourier transform infrared (FTIR) spectra of the biochars and bagasse feedstock were established in the range $\quad 400-4000 \quad \mathrm{~cm}^{-1} \quad$ (SHIMADZU infrared spectrophotometer; model FT/IR-5300, JASCO Corporation) to determine predominant surface functional groups. Images of a scanning electron microscope (SEM, Jeol model 6360 OLA) was used to investigate the surface micro-morphology of biochars.

For comparison, Zeolite and Charcoal, as commercial adsorbents, were purchased from private companies to be used for the comparison with the generated biochars for their efficiencies of ammonium and phosphate ions removal from aqueous solutions.

\section{Stock solution of ammonium and phosphate:}

A stock solution containing $500 \mathrm{mg} \mathrm{P} / \mathrm{l}$ and $580 \mathrm{mg}$ $\mathrm{NH}_{4}{ }^{+} / 1$ was prepared using an analytical grade of diammonium orthophosphate salt $(2.129 \mathrm{~g}$ $\left.\left(\mathrm{NH}_{4}\right)_{2} \mathrm{HPO}_{4} / \mathrm{l}\right)$. From the stock solution, aqueous solutions with a series of $\mathrm{NH}_{4}^{+}$and $\mathrm{P}$ concentrations were prepared for the proposed adsorption experiments.

\section{Kinetics of ammonium and phosphate sorption:}

The kinetics of ammonium and phosphate removal by the four sorbents (SCBB, Mg-SCBB, Zeolite, and Charcoal) from aqueous solutions was investigated using the compartment method. Artificial aqueous solutions containing $23.2 \mathrm{ppm} \mathrm{NH}_{4}^{+}$and $20 \mathrm{ppm} \mathrm{P}$ (representing average concentrations of such species in local municipal wastewater) were prepared from the stock solution. In a double jacket reaction vessel (Fig. 1), 2 or $5 \mathrm{~g}$ of each sorbent was suspended in $1000 \mathrm{ml}$ aqueous solution to represent 1:200 or 1:500 sorbent to solution ratio. The reaction took place in the inner vessel. The suspension was continuously stirred at 500 rpm using magnetic stirrer and temperature of the suspension was kept constant at $25^{\circ} \mathrm{C}$ using a continuous circulating thermostatic water system running in the outer vessel and surrounding the reaction inner vessel. Subsamples of suspension $(20 \mathrm{ml})$ were withdrawn from the reaction vessel using a manual syringe at time intervals of 1, 2, 3, 4, 6, 8, 10, 12 and 24 $\mathrm{h}$ and $\mathrm{pH}$ of the sampled suspensions was immediately measured. The suspensions were then filtered through a filter paper (Whatman no. 1) and the equilibrium concentrations of ammonium and phosphate were measured in the filtrates. The concentrations of ammonium and phosphate were determined colorimetrically according to the methods described by Keeney and Nelson (1982) and Murphy and Riley (1962), respectively. 


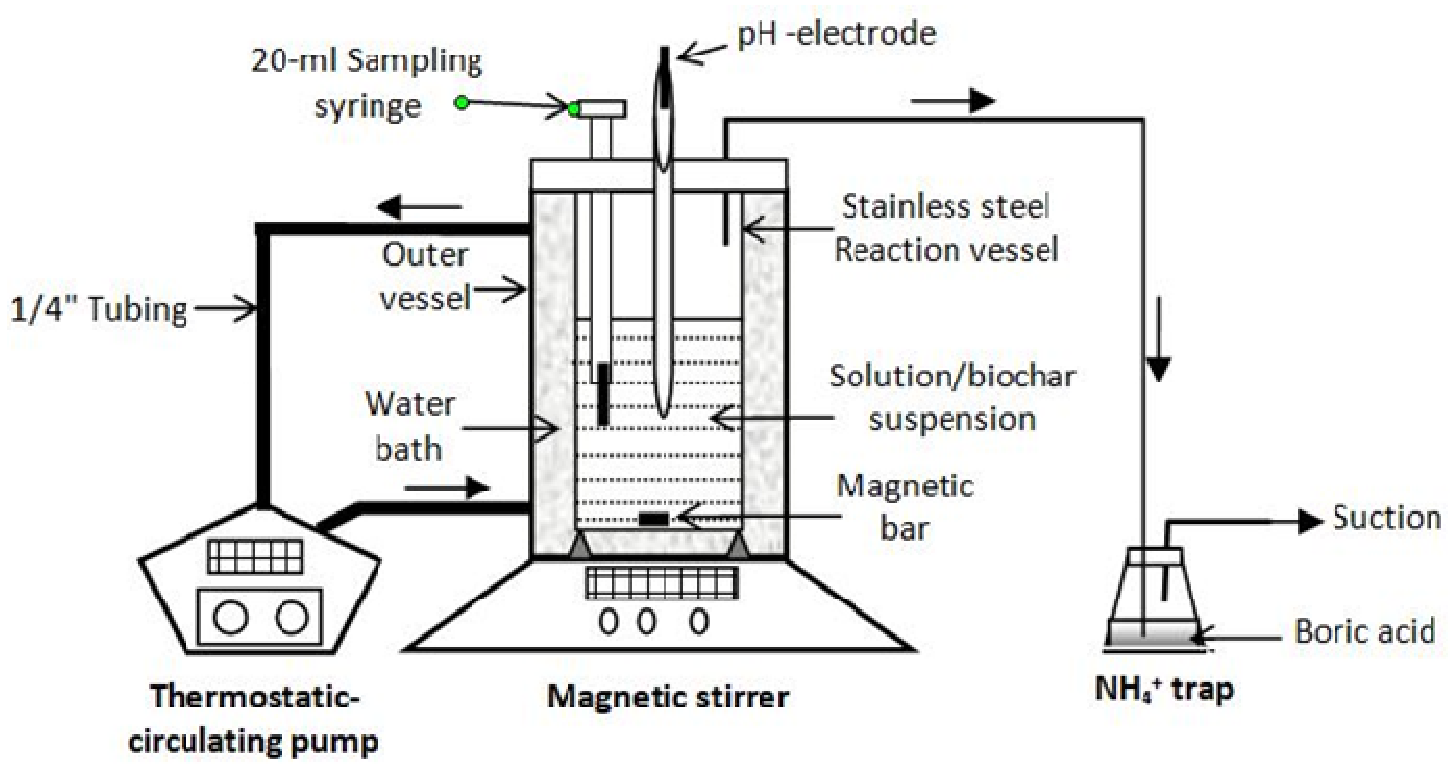

Fig. 1. The double-jacket reaction vessel used in the adsorption experiments

The amount of ammonium and phosphate adsorbed per sorbent unit mass $\left(\mathrm{q}, \mathrm{mg} \mathrm{g}^{-1}\right)$ were calculated using equation (1).

$$
q=\frac{\left(C_{o}-C_{e q}\right)}{m} v
$$

Where $\mathrm{C}_{0}$ and $\mathrm{C}_{\mathrm{eq}}$ are the initial and equilibrium concentrations $(\mathrm{mg} / \mathrm{l})$, respectively, $\mathrm{m}$ is the mass of sorbent material $(\mathrm{g})$, and $\mathrm{v}$ is the volume of aqueous solution (1).

For correction of ammonia volatilization, the evolved ammonia from the reaction vessel at each time interval was collected and trapped in $25 \mathrm{ml}$ of boric acid for its measurement. Plots of sorption kinetics (time vs. q) were established and the equilibrium time was evaluated. The fitness of these plots to the first- and second-order mathematical models of reaction kinetics was also investigated.

The removal percentage of adsorbate $(\mathrm{R}, \%)$ was also calculated from Equation (2) as follows;

$$
R \%=\frac{\left(C_{0}-C_{e q}\right)}{C_{0}} \times 100
$$

\section{Isotherms of ammonium and phosphate sorption:}

Sorption isotherms of $\mathrm{NH}_{4}^{+}$and $\mathrm{P}$ on the investigated sorbents were established using the 1:200 and 1:500 suspension ratios and a series of initial concentrations of $\mathrm{NH}_{4}{ }^{+}(23.2,46.4$ and $92.6 \mathrm{ppm})$ and $\mathrm{P}$ (20, 40 and $80 \mathrm{ppm})$. The sorption reaction was conducted for each individual sorbent under the same conditions of the aforementioned kinetic experiment (stirring at $500 \mathrm{rpm}$ and temperature at $25{ }^{\circ} \mathrm{C}$ ).
Suspensions were sampled at the equilibrium time determined from the kinetic experiment. Similarly, $\mathrm{pH}$ was measured immediately in the suspension and $\mathrm{NH}_{4}{ }^{+}$ and $\mathrm{P}$ were also measured in the filtrate using the same methods. Ammonia volatilization was also determined for the correction of sorbed $\mathrm{NH}_{4}{ }^{+}$. Sorption isotherms were plotted ( $\mathrm{q}$ vs. $\mathrm{C}_{\mathrm{eq}}$ ) and the fitness to Freundlich and Langmuir adsorption mathematical models were tested.

\section{Mathematical Models}

\section{Kinetic models:}

The model expressed in Equation (3) was used to describe the intra-particle diffusion as the controlling step for the adsorption process (Weber and Morris, 1963; Zhang et al., 2015).

$$
q_{t}=K_{p} t^{1 / 2}+C
$$

Where $k_{p}$ is the rate constant of intra-particle diffusion $\left(\mathrm{mg} / \mathrm{g} \cdot \mathrm{min}^{1 / 2}\right)$, and $\mathrm{C}(\mathrm{mg} / \mathrm{g})$ is the intercept. A linear plot of $\mathrm{q}_{\mathrm{t}}$ against $\mathrm{t}^{1 / 2}$ can be used to test the goodness-of-fit of the experimental data to the pseudofirst-order model.

The Lagergren pseudo-first-order kinetic model can be expressed by Equation (4)

$$
\frac{d q_{t}}{d t}=k_{1}\left(q_{e}-q_{t}\right)
$$

Where $\mathrm{k}_{1}$ is the adsorption rate constant $(\mathrm{g} / \mathrm{min}), \mathrm{q}_{\mathrm{e}}$ is the amount of phosphate adsorbed at equilibrium $(\mathrm{mg} / \mathrm{g})$, and $\mathrm{q}_{\mathrm{t}}$ is the amount of adsorbed phosphate at time $\mathrm{t}(\mathrm{mg} / \mathrm{g})$. For limits of the initial conditions from 
$\mathrm{q}_{\mathrm{t}}=0$, at $\mathrm{t}=0$ to $\mathrm{q}_{\mathrm{t}}=\mathrm{q}_{\mathrm{t}}$ at time $\mathrm{t}$, the integration of Equation (5) yields:

$$
q_{t}=q_{e}\left[1-\exp \left(-k_{1} t\right)\right]
$$

The linearized form of this integral can be expressed in Equation (6);

$$
\ln \left(q_{t}-q_{e}\right)=\ln q_{e}+k_{1} t
$$

Where $\mathrm{q}_{\mathrm{e}}$ and $\mathrm{k}_{1}$ can be obtained from the regression plot of $\ln \left(\mathrm{q}_{\mathrm{t}}-\mathrm{q}_{\mathrm{e}}\right)$ against $\mathrm{t}$.

The pseudo-second-order model (Ho and McKay, 1999; Ho, 2006) can be expressed by Equation (7):

$$
\frac{d q_{t}}{d t}=k_{2}\left(q_{e}-q_{t}\right)^{2}
$$

The integration of the of Equation (7) for the initial conditions $\mathrm{q}_{\mathrm{t}}=0$ at $\mathrm{t}=0$ yields

$$
q_{t}=\frac{q_{e}^{2} k_{2} t}{1+q_{e} k_{2} t}
$$

Where $\mathrm{k}_{2}$ is the adsorption rate constant $(\mathrm{g} / \mathrm{mg} \min ), \mathrm{q}_{\mathrm{e}}$ is the amount of adsorbed phosphate $(\mathrm{mg} / \mathrm{g})$ at equilibrium, and $\mathrm{q}_{\mathrm{t}}$ is the amount of adsorbed phosphate at time $\mathrm{t}(\mathrm{mg} / \mathrm{g})$.

The linearization of Equation (8) was developed in different versions (Ho, 2006; Ghasemi et al., 2013; Plazinski et al., 2013) as presented in Table (1).

Table 1. Different versions of pseudo-second-order model used for adsorption kinetics studies

\begin{tabular}{lc}
\hline Linearized versions & Equation No. \\
\hline$\frac{t}{q}=\frac{1}{k q_{e}^{2}}+\frac{1}{q_{e}} t$ & $8-1$ \\
$\frac{1}{q}=\frac{1}{q_{e}}+\left(\frac{1}{k q_{e}^{2}}\right)+\frac{1}{t}$ & $8-2$ \\
$q=q e-\left(\frac{1}{k q_{e}}\right) \frac{q}{t}$ & $8-3$ \\
$\frac{q}{t}=k q_{e}^{2}-k q_{e} q$ & $8-4$ \\
\hline
\end{tabular}

\section{Models for sorption isotherms:}

The empirical Freundlich linearized model expressed in Equation (9) was used to describe the relation between the amount of adsorbed ammonium or phosphate $\left(\mathrm{q}_{\mathrm{e}}\right)$ on biochar and their concentration $\left(\mathrm{C}_{\mathrm{e}}\right)$ at equilibrium.

$$
\log q e=\log k_{f}+\frac{1}{n} \log C_{e}
$$

Where $K_{f}$ and $1 / n$ are the constants that reflect the capacity and intensity of adsorption. These constants can be calculated from the plots of $\log \mathrm{q}_{\mathrm{e}}$ against $\log \mathrm{C}_{\mathrm{e}}$, were $1 / n$ equals the slope of the straight line and $K_{f}$ equals its intercept.

Also, the commonly applied Langmuir linearized model is expressed in Equation (10).

$$
\frac{C_{e}}{q_{e}}=\frac{C_{e}}{q_{\max }}+\frac{1}{q_{\max } K_{1}}
$$

Where $\mathrm{q}_{\max }$ is the maximum monolayer adsorption capacity $\left(\mathrm{mg} \mathrm{kg}^{-1}\right)$ and $\mathrm{K}_{\mathrm{L}}$ is a constant that reflects the favorability of the adsorption process. The plots of $\mathrm{C}_{\mathrm{e}} / \mathrm{q}_{\mathrm{e}}$ against $C_{e}$ give a straight line whose slope equals $1 / q_{\max }$ and the intercept equals $1 / \mathrm{q}_{\max } \mathrm{K}_{\mathrm{L}}$.

Data of the sorption kinetics experiments were analyzed to find the most successful mathematical model to describe the removal of ammonium and phosphate by the generated sugarcane bagasse biochars. The least squared differences technique was applied and the Coefficient of determination $\left(\mathrm{R}^{2}\right)$ was used as the statistical criteria for the goodness-of-fit of the tested models to the experimental data.

\section{RESULTS AND DISCUSSION}

\section{Characteristics of generated biochars:}

\section{Physical characteristics:}

When $200 \mathrm{~g}$ of sugarcane bagasse feedstock (SCBF) was soaked in the $\mathrm{MgSO}_{4}$ solution and then dried at $80{ }^{\circ} \mathrm{C}$, the final weight obtained was $302.82 \mathrm{~g}$. The percent increase in the Mg-impregnated feedstock was $54.41 \%$ and it was due to the absorbed amount of $\mathrm{MgSO}_{4}$ salt within the capillary tissue of the sugarcane bagasse. After pyrolysis at $500{ }^{\circ} \mathrm{C}, 51.16$ and $105.93 \mathrm{~g}$ of SCBB and $\mathrm{Mg}-\mathrm{SCBB}$ were obtained, respectively. Thus, the calculated biochar yields from feedstock were 25.58 and $34.98 \%$ on the dried mass basis (Table 2). This was due to dehydration and condensation processes. Volatile matter contents were calculated to be 74.42 and $65.02 \%$ for SCBB and Mg-SCBB, respectively. $\mathrm{SCBB}$ ash and moisture contents were lower than those of $\mathrm{Mg}$-SCBB due to the higher $\mathrm{Mg}$ content of the latter. The generated SCBB biochar had a black color and $\mathrm{Mg}$-SCBB had a dark gray color and higher ash content due also to its high $\mathrm{Mg}$ content.

\section{Chemical characteristics:}

The generated SCBB and Mg-SCBB had higher $\mathrm{pH}$ values than $\mathrm{SCBF}$ (Table 2) and $\mathrm{Mg}$-SCBB was more alkaline than SCBB. In addition, the EC values $\left(\mathrm{dS} \mathrm{m}^{-1}\right)$ of SCBB and Mg-SCBB were slightly higher compared to its value for SCBF feedstock (Table 2). Carbon, hydrogen, nitrogen, and sulfur contents of biochars were higher than the bagasse feedstock due to condensation and they were comparable to those 
Table 2.Main physical and chemical characteristics of sugarcane bagasse feedstock and the tested sorbents

\begin{tabular}{|c|c|c|c|c|c|}
\hline \multirow{2}{*}{ Criteria } & \multirow{2}{*}{$\begin{array}{c}\text { SCBF } \\
\text { Feedstock }\end{array}$} & \multicolumn{2}{|c|}{ Biochars } & \multirow{2}{*}{ Charcoal } & \multirow{2}{*}{ Zeolite } \\
\hline & & SCBB & Mg-SCBB & & \\
\hline \multicolumn{6}{|l|}{ Physical characteristics } \\
\hline Biochar yield, \% & - & 25.58 & 34.98 & - & - \\
\hline Volatile matter, $\%$ & - & 74.42 & 65.02 & - & - \\
\hline Ash, $\%$ & - & 15.61 & 20.64 & - & - \\
\hline Color & - & black & dark gray & black & white \\
\hline Surface area, $\mathrm{m}^{2} \mathrm{~g}^{-1}$ & - & 38.74 & 42.12 & 35.61 & 49.87 \\
\hline \multicolumn{6}{|c|}{ Chemical characteristics } \\
\hline$E C, d_{S} m^{-1}$ & 0.70 & 0.95 & 1.02 & 0.87 & 0.74 \\
\hline $\mathrm{pH}$ & 3.36 & 7.09 & 9.88 & 8.95 & 6.95 \\
\hline $\mathrm{CEC}, \mathrm{cmol} \mathrm{kg}^{-1}$ & - & 34.74 & 39.57 & 31.24 & 48.02 \\
\hline $\mathrm{C}, \%$ & 42.82 & 67.61 & 64.35 & 65.84 & - \\
\hline $\mathrm{N}, \%$ & 0.55 & 0.79 & 0.73 & 0.76 & - \\
\hline $\mathrm{C} / \mathrm{N}$ ratio & 77.85 & 85.6 & 88.2 & 86.63 & - \\
\hline $\mathrm{S}, \%$ & 0.42 & 0.39 & 0.34 & 0.41 & - \\
\hline
\end{tabular}

obtained by many researchers (Saleh et al., 2013; Jindo et al., 2014; El-Gamal et al., 2017). The elemental contents for $\mathrm{Mg}$ -

SCBB were slightly lower compared to SCBB presumably due to its higher $\mathrm{Mg}$ content. Condensation led also to the increase in the $\mathrm{C} / \mathrm{N}$ ratio from 77.85 for bagasse feedstock to 85.6 and 88.2 for SCBB and Mg$\mathrm{SCBB}$, respectively. Sulfur content was slightly reduced after pyrolysis (Table 2).

\section{Surface functional groups by FTIR analysis:}

The FTIR spectra of SCB feedstock and the generated biochars SCBB and $\mathrm{Mg}$-SCBB are presented in Fig. (2). Generally, the peaks obtained for the three materials are different in their wave numbers peaks and intensities. Peaks of O-H stretching of free hydroxyl group were observed within the range from 3813.4 and $3786.39 \mathrm{~cm}^{-1}$, from 3875.12 to $3757.46 \mathrm{~cm}^{-1}$, and from 3861.62 to $3734.31 \mathrm{~cm}^{-1}$, for SCBF, SCBB, and Mg$\mathrm{SCBB}$, respectively indicating the chemically adsorbed water molecules and surface hydroxyl groups. SCBF had the highest intensity of free $\mathrm{OH}$ peaks and it was much lesser in SCBB and Mg-SCBB (Saleh et al., 2013). This may indicate the loss of free water molecules from SCBF during the pyrolysis process at $500 \circ \mathrm{C}$.

The presence of $\mathrm{OH}$ groups and $\mathrm{H}$-bonds bands of alcohols and phenols were observed at peaks 3410.26 , 3446.91, and $3396.76 \mathrm{~cm}^{-1}$ for SCBF, SCBB, and MgSCBB, respectively (Jindo et al., 2014). The intensities of these peaks were the highest for Mg-SCBB (Daffalla et al., 2010). This may be due to the initial impregnation of SCBF with a $\mathrm{MgSO}_{4}$ solution, heating at 105 and the formation of $\mathrm{MgO}$ due to $\mathrm{SO}_{2}$ gas evolution and the formation of a surface precipitate of metal oxide and

hydroxide surfaces (Claoston et al., 2014; Sizmur et al., 2017).

Peaks assigned to aliphatic $\mathrm{C}-\mathrm{H}$ vibrational stretching appeared in SCBF spectrum at $2921.61 \mathrm{~cm}^{-1}$ indicating the presence of alkanes. However, this peak was not detected in SCBB or in Mg-SCBB spectra. This may indicate dehydration of cellulosic and ligneous components and thus the dehydrogenation of methylene groups of bagasse feedstock which led to a condensed structure of the generated biochars. Peaks of stretching $\mathrm{C} \equiv \mathrm{C}$ existed in $\mathrm{SCBF}, \mathrm{SCBB}$, and $\mathrm{Mg}-\mathrm{SCBB}$ spectra at $2142.99,2357.09$, and $2349.38 \mathrm{~cm}^{-1}$, respectively, with descending intensity in the order:Mg-SCBB > SCBB > $\mathrm{SCBF}$ which is consistent with increasing the degree of condensation due to pyrolysis. Peaks at 1633.76, 1583.61, and $1660.77 \mathrm{~cm}^{-1}$ assigned to $\mathrm{C}=\mathrm{O}$ groups stretching were detected in SCBF, SCBB, and $\mathrm{Mg}$ SCBB (Harvey et al., 2012; Saleh et al., 2013 and Yao et al., 2013).

Aromatic $\mathrm{C}=\mathrm{C}$ stretching bands, an indication of benzene-like rings, were also indicated by the peaks at 1402.30, 1417.73, and $1446.66 \mathrm{~cm}^{-1}$ in SCBF, SCBB, and $\mathrm{Mg}$-SCBB spectra, respectively, with higher peak intensity in SCBB and Mg-SCBB spectra (Harvey et al., 2012; Saleh et al., 2013; El-Gamal et al., 2017). Bands appeared at $500-700 \mathrm{~cm}^{-1}$ may indicate the presence of halide-alkyl vibrational stretching and/or inorganic metal compounds such as of $\mathrm{Ca}, \mathrm{Mg}$, or $\mathrm{K}$ (Claoston et al., 2014).

Similarities and differences in the characteristic surface functional groups of SCBF and the generated biochars reveal that changes occurred in the molecular structure and surface configuration of the generated biochars leading to the loss of aliphatic, alcohol and 

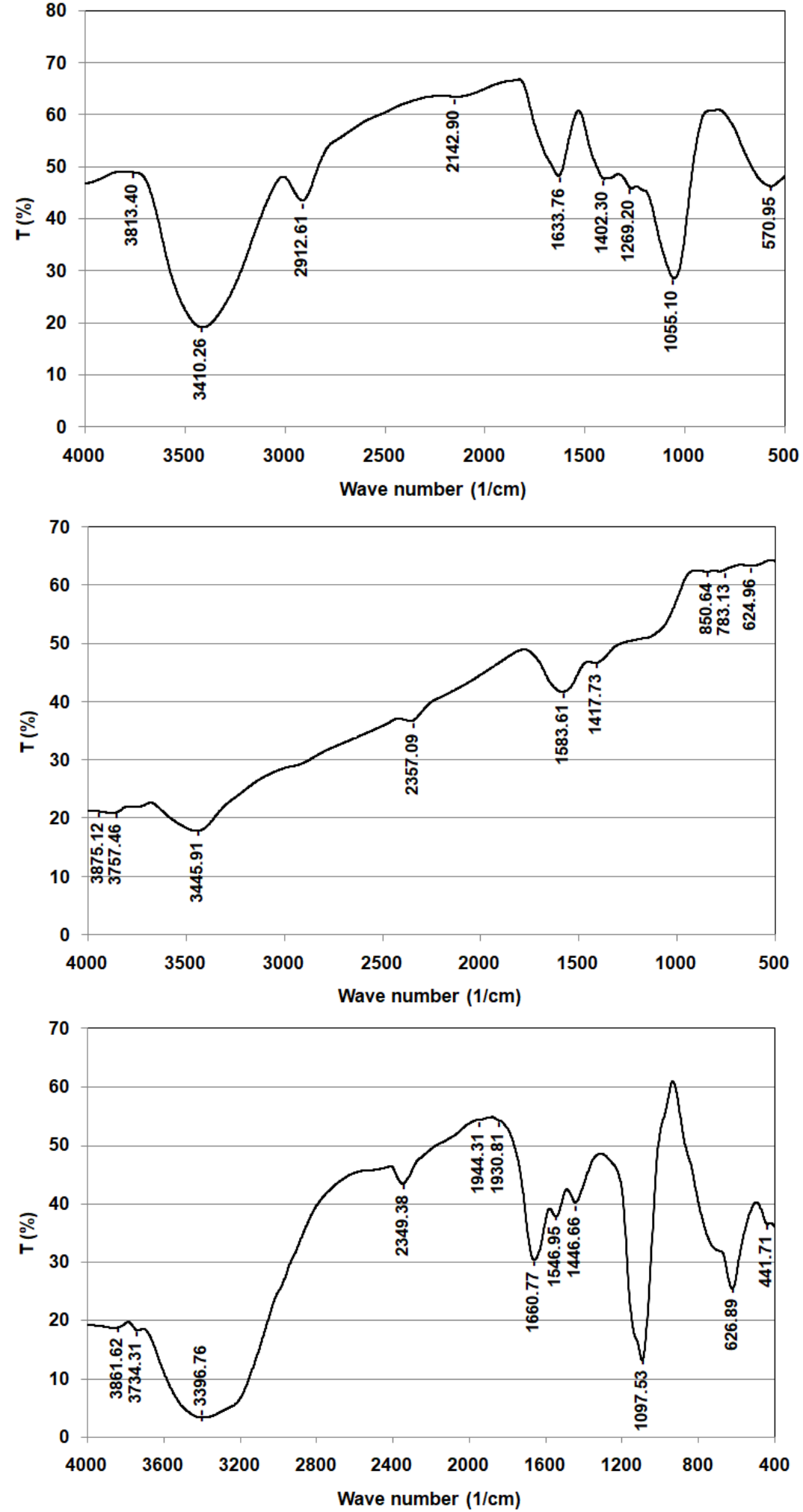

Fig. 2. FTIR spectra of SCB feedstock (top), SCBB (middle), and Mg-SCBB (bottom) 

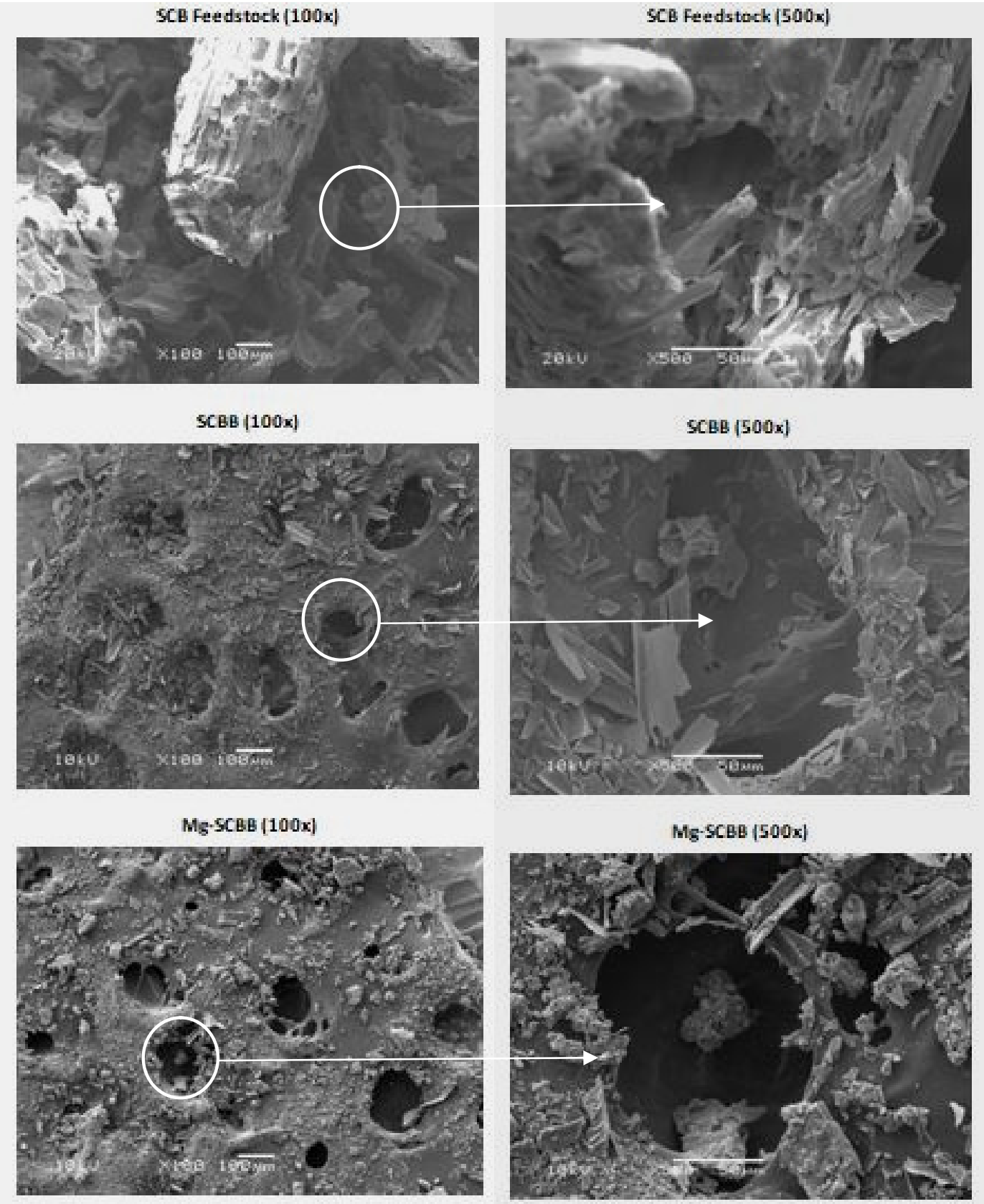

Fig. 3.SEM images of SCB feedstock (top), SCBB (middle), and Mg-SCBB (bottom) at 100x (left) and 500 x (right) magnifications

alkane compound, sugar, and cellulosic and the increase in the aromaticity as temperature increases during pyrolysis (Liu et al., 2015; Carrier et al., 2012; Saleh et al., 2013; El-Gamal et al., 2017).

\section{Microstructure using SEM imaging.}

The microstructure of SCBF, SCBB, and Mg-SCBB was investigated by SEM imaging (Fig. 3). It can be observed that SCBF has a complex porous network and that it has fibrous, smooth surfaces in which macropores are dominant. However, pyrolysis at $500{ }^{\circ} \mathrm{C}$ led to coarse surfaces of the generated biochars specially $\mathrm{Mg}$ SCBB and a more porous structure can be seen in the SEM images. More meso- and micropores in the generated SCBB biochar were developed on the account of macropores. Micropores were even increased in $\mathrm{Mg}-$ SCBB biochar compared to SCBB. The development of these micropores in $\mathrm{Mg}$-SCBB may explain the higher surface area measured for this modified biochar (Table 2). Due to $\mathrm{MgSO}_{4}$ impregnation, surface coverage with $\mathrm{Mg}(\mathrm{OH})_{2}$ or $\mathrm{MgO}$ crystals could be also identified on 
Mg-SCBB surfaces compared to SCBB. Changes in the pore configurations of the generated biochars compared with the feedstock are presumably due to the thermal decomposition of cellulose and hemicellulose during the pyrolysis process leaving the cell walls which has higher proportions of lignin compounds. These results are similar to those obtained by Bonelli et al. (2006), Carrier et al. (2012), Harvey et al. (2012), Saleh et al. (2013); Liu et al. (2015), and El-Gamal et al. (2017) who observed similar changes in the surface morphology and size distribution of pores of biochars generated by the pyrolysis of sugarcane bagasse and other agricultural waste materials. These changes were found to be dependent on the type of feedstock, pyrolysis temperature, and the pre- or post-pyrolysis treatments (El-Gamal et al., 2017; Sizmur et al., 2017).

\section{Adsorption kinetics of ammonium and phosphate ions:}

Results of adsorption kinetics of ammonium ions (Fig. 4) revealed that sorption of ammonium from aqueous solutions by the tested sorbents was very fast during the first two hours. SCBB and $\mathrm{Mg}-\mathrm{SCBB}$ were capable of removing ammonium from the aqueous solution at both 1:200 and 1:500 sorbent to solution ratios. For 1:200 ratio and $23 \mathrm{mg} / \mathrm{l}$ of initial ammonium concentration, the maximum ammonium removal percent had the order: Zeolite> Mg-SCBB> SCBB> Charcoal (96.41, 80.38, 67.87, and 61.81\%, respectively) and were achieved after $12 \mathrm{~h}$ of contact time. However, the ammonium removal percents for these sorbents were very close to each other at 1:500 ratio and they were generally lower than those at 1:200 (72.78, 52.58, 51.13, and 50.19\%, for Zeolite, MgSCBB, SCBB, and Charcoal, respectively). The developed meso- and micropores in the porous structure, due to modification by $\mathrm{MgSO}_{4}$ impregnation of SCBF, enhanced the efficiency of $\mathrm{Mg}-\mathrm{SCBB}$ to remove ammonium from solution compared with SCBB and it performed comparably to Zeolite and Charcoal. Similar results were obtained Yao et al. (2013), Fang et al. (2014) and Takaya et al. (2016) who found that pretreatments of biomasses with metal solutions enhanced the efficiency of the generated biochars in removing inorganic ions $\left(\mathrm{NH}_{4}^{+}, \mathrm{NO}_{3}^{-}, \mathrm{PO}_{4}-\mathrm{P}\right)$ from aqueous solutions.

Ammonia volatilization continued during the ammonium adsorption process due to the alkaline conditions of the solution (Fig. 5). Mg-SCBB exhibited the highest cumulative ammonia volatilization. This could be explained by its strong alkaline effect due to $\mathrm{MgO}$ hydrolysis compared with the other sorbents (Fig. 6). However, SCBB and Zeolite recorded the least cumulative ammonia volatilization due to their lower solution $\mathrm{pH}$. Cumulative ammonia volatilization for the tested sorbents did not change considerably between the $1: 200$ and 1:500 ratios.
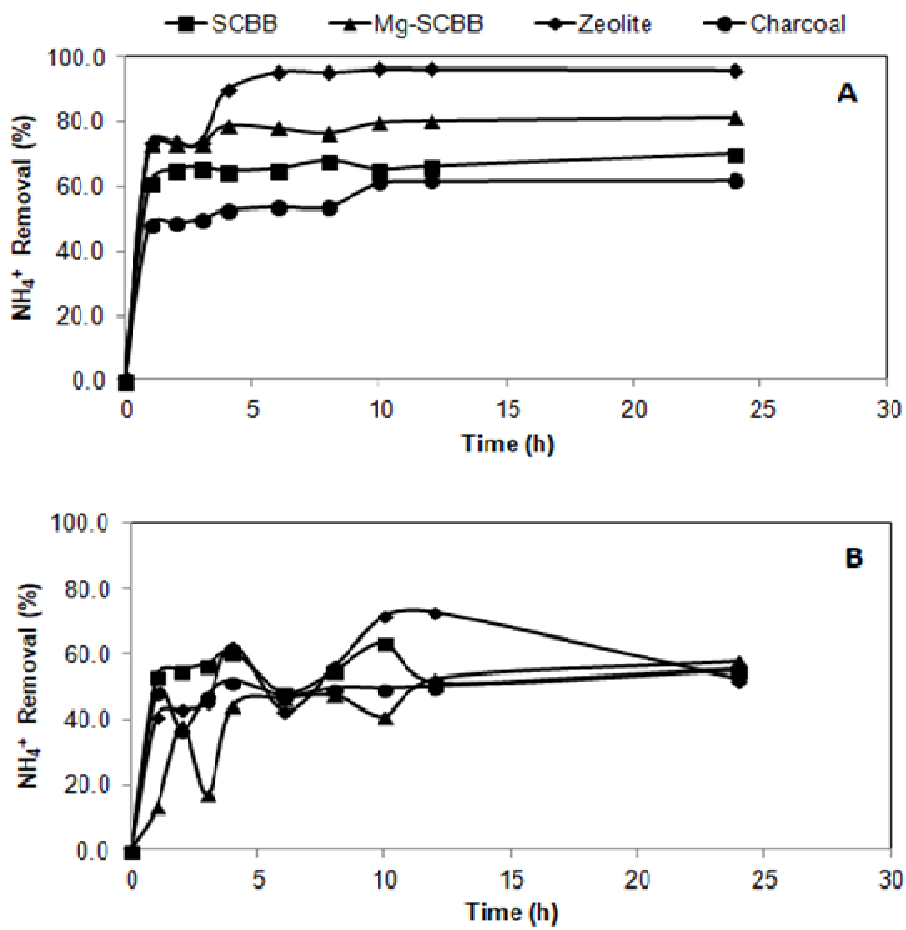

Fig. 4. Percent of $\mathrm{NH}_{4}{ }^{+}$removal from aqueous solutions by different sorbents at A) 1:200, and B) 1:500 sorbent: solution ratios 

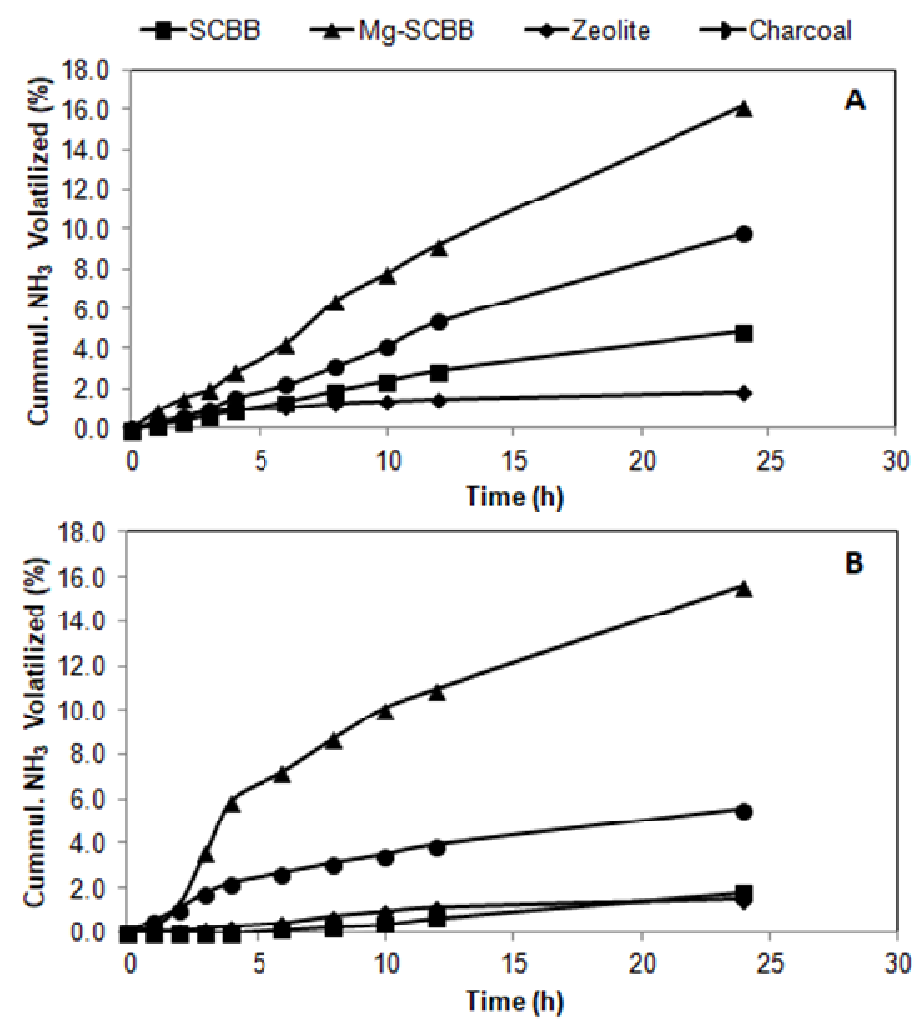

Fig. 5. Cumulative percent of ammonia volatilization during $\mathrm{NH}_{4}^{+}$sorption from aqueous solutions by different sorbents at $A$ ) 1:200, and B) 1:500 sorbent: solution ratios
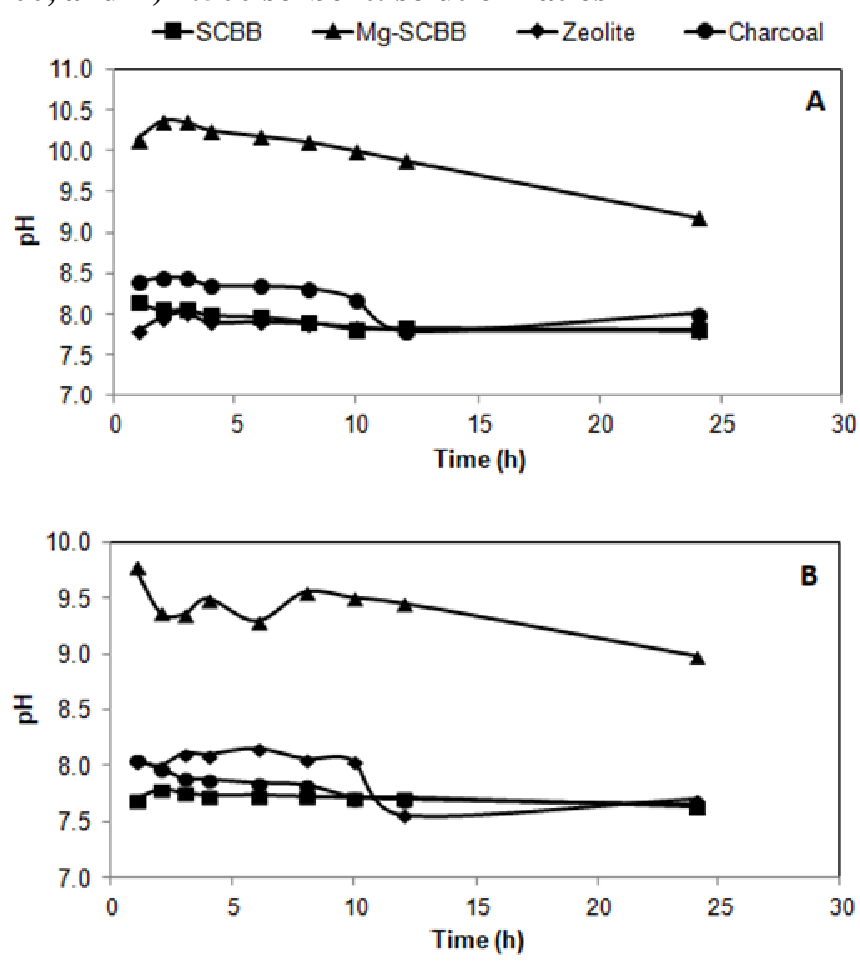

Fig. 6. Changes in $\mathrm{pH}$ during $\mathrm{NH}_{4}{ }^{+}$or $\mathrm{P}$ removal from aqueous solutions by different sorbents at $\left.\mathrm{A}\right) 1: 200$, and B) 1:500 sorbent: solution ratios 


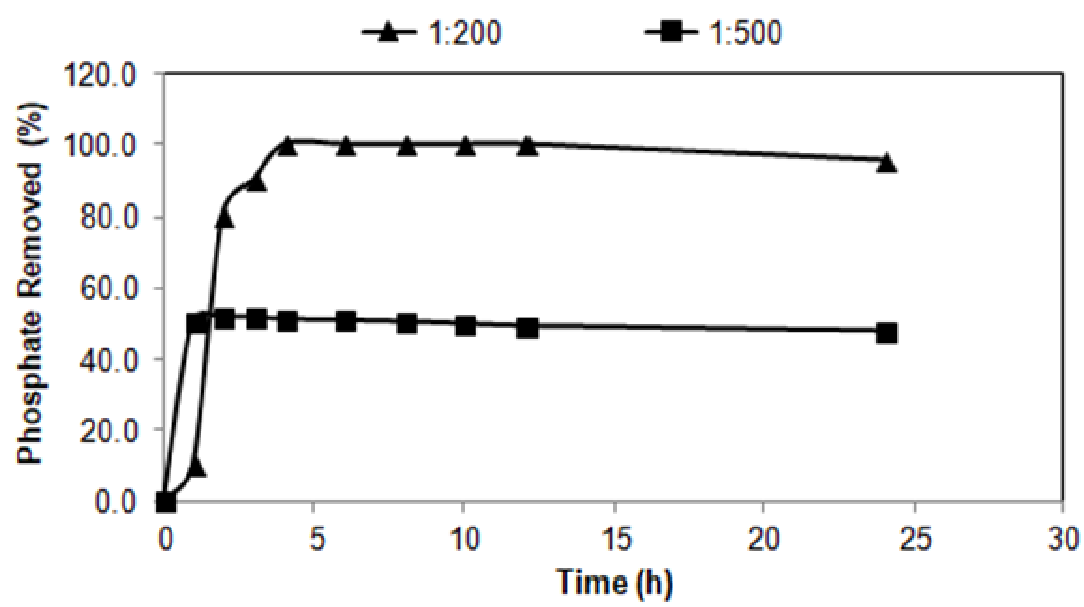

Fig. 7. Percent of phosphate removal from aqueous solutions by Mg-SCBB at 1:200 and 1:500 sorbent: solution ratios

Table 3. Regression parameters of fitting $\mathrm{NH}_{4}{ }^{+}$and $\mathrm{P}$ adsorption kinetics data to different linear forms of pseudo-second-order equation

\begin{tabular}{|c|c|c|c|c|c|c|c|c|c|c|}
\hline Sorbate/Sorbent & Ratio & Eq. & Slope & Intercept & $\mathbf{R}^{2}$ & Sorbate/Sorbent & Ratio & Slope & Intercept & $\mathbf{R}^{2}$ \\
\hline \multirow[t]{4}{*}{ NH4/SCBB } & $1: 500$ & $6-1$ & $1.0 \mathrm{E}-04$ & $1.0 \mathrm{E}-04$ & 0.997 & $\mathrm{P} / \mathrm{Mg}-\mathrm{SCBB}$ & $1: 200$ & $2.0 \mathrm{E}-04$ & $2.0 \mathrm{E}-04$ & 0.991 \\
\hline & & $6-2$ & $5.0 \mathrm{E}-05$ & $1.0 \mathrm{E}-04$ & 0.628 & & & $4.0 \mathrm{E}-04$ & $2.0 \mathrm{E}-04$ & 0.901 \\
\hline & & $6-3$ & -0.5921 & 7419.6 & 0.914 & & & -1.1649 & 4621.6 & 0.870 \\
\hline & & $6-4$ & -1.5431 & 11682 & 0.914 & & & -0.7464 & 3613.7 & 0.870 \\
\hline \multirow[t]{4}{*}{ NH4/SCBB } & $1: 200$ & 1 & $3.0 \mathrm{E}-04$ & $1.0 \mathrm{E}-04$ & 0.999 & NH4/Zeolite & $1: 500$ & $1.0 \mathrm{E}-04$ & $1.0 \mathrm{E}-04$ & 0.997 \\
\hline & & 2 & $3.0 \mathrm{E}-05$ & $3.0 \mathrm{E}-04$ & 0.682 & & & $5.0 \mathrm{E}-05$ & $1.0 \mathrm{E}-04$ & 0.629 \\
\hline & & 3 & -0.5865 & 3466.2 & 0.763 & & & -0.5918 & 7418 & 0.914 \\
\hline & & 4 & -1.3007 & 4801.1 & 0.763 & & & -1.544 & 11687 & 0.914 \\
\hline \multirow[t]{4}{*}{ NH4/Mg-SCBB } & $1: 500$ & 1 & $1.0 \mathrm{E}-04$ & $4.0 \mathrm{E}-05$ & 1.000 & NH4/Zeolite & $1: 200$ & $2.0 \mathrm{E}-04$ & $1.0 \mathrm{E}-04$ & 0.998 \\
\hline & & 2 & $1.0 \mathrm{E}-05$ & $1.0 \mathrm{E}-04$ & 0.929 & & & $9.0 \mathrm{E}-05$ & $2.0 \mathrm{E}-04$ & 0.659 \\
\hline & & 3 & -0.5837 & 8750.6 & 0.750 & & & -0.8361 & 4858.5 & 0.802 \\
\hline & & 4 & -1.2851 & 12023 & 0.750 & & & $-9.6 \mathrm{E}-01$ & 4943.5 & 0.802 \\
\hline \multirow[t]{4}{*}{ NH4/Mg-SCBB } & $1: 200$ & 1 & $3.0 \mathrm{E}-04$ & $1.0 \mathrm{E}-04$ & 0.999 & NH4/Charcoal & $1: 500$ & $1.0 \mathrm{E}-04$ & $1.0 \mathrm{E}-04$ & 0.997 \\
\hline & & 2 & $3.0 \mathrm{E}-05$ & $3.0 \mathrm{E}-04$ & 0.605 & & & $4.0 \mathrm{E}-05$ & $1.0 \mathrm{E}-04$ & 0.618 \\
\hline & & 3 & -0.6287 & 4078 & 0.681 & & & -0.5789 & 7306.8 & 0.911 \\
\hline & & 4 & -1.083 & 4852 & 0.681 & & & -1.5735 & 11738 & 0.911 \\
\hline \multirow[t]{4}{*}{$\mathrm{P} / \mathrm{Mg}-\mathrm{SCBB}$} & $1: 500$ & 1 & $1.0 \mathrm{E}-04$ & $2.0 \mathrm{E}-05$ & 0.996 & NH4/Charcoal & $1: 200$ & $4.0 \mathrm{E}-04$ & $2.0 \mathrm{E}-04$ & 0.996 \\
\hline & & 2 & $1.0 \mathrm{E}-04$ & $9.0 \mathrm{E}-05$ & 0.710 & & & $3.0 \mathrm{E}-05$ & 4.0E-04 & 0.210 \\
\hline & & 3 & -0.8975 & 10281 & 0.736 & & & -0.477 & 2572.8 & 0.834 \\
\hline & & 4 & -0.8195 & 9197.2 & 0.736 & & & -1.7482 & 4671.9 & 0.834 \\
\hline
\end{tabular}

The total removal percent of ammonium (adsorbed + volatilized) was calculated for the tested sorbents after $12 \mathrm{~h}$ and at 1:200 ratios and it was found to follow the order: Zeolite> Mg-SCBB> SCBB> Charcoal (95.89, $89.59,70.78$ and $67.17 \%$, respectively).

Although adsorption of phosphate from aqueous solutions was not observed at all for Zeolite, Charcoal or SCBB, it was only evident for Mg-SCBB. Maximum removal percent of phosphate by $\mathrm{Mg}-\mathrm{SCBB}$ was reached after $2 \mathrm{~h}$ of contact time (Fig. 7). Phosphate removal was higher at 1:200 than at 1:500 ratios (79.88 and $50.01 \%$, respectively) exhibiting the same kinetic trend at the two ratios. Yao et al. (2013) found that $\mathrm{Mg}$ modified biochars were found to have a better ability of phosphate removal from aqueous solutions. They reported that $\mathrm{Mg}(\mathrm{OH})_{2}$ and $\mathrm{MgO}$ nanoparticles were developed on the particles' surfaces of Mg-modified biochars which served as the sorption sites for aqueous phosphate.

Fitting the sorption data of ammonium and phosphate kinetics models revealed that the pseudosecond-order equation (Eq. 6) was capable of representing the experimental data. 
Table 4. Adsorption kinetics parameters calculated from fitting the linearized form of pseudo-second-order equation (Eq. 6-1)

\begin{tabular}{lccccc}
\multicolumn{1}{c}{ Sorbate/sorbent/ratio } & Slope & Intercept & $\mathbf{R}^{\mathbf{2}}$ & $\begin{array}{c}\mathbf{q}_{\mathbf{e}} \\
\mathbf{m g ~ k g}^{-1}\end{array}$ & $\mathbf{k}$ \\
\hline $\mathrm{NH}_{4} / \mathrm{SCBB} / 200$ & $3.0 \mathrm{E}-04$ & $1.0 \mathrm{E}-04$ & 0.999 & 3333.3 & $9.0 \mathrm{E}-04$ \\
$\mathrm{NH}_{4} / \mathrm{SCBB} / 500$ & $1.0 \mathrm{E}-04$ & $1.0 \mathrm{E}-04$ & 0.997 & 10000.0 & $1.0 \mathrm{E}-04$ \\
$\mathrm{NH}_{4} / \mathrm{Mg}-\mathrm{SCBB} / 200$ & $3.0 \mathrm{E}-04$ & $1.0 \mathrm{E}-04$ & 0.999 & 3333.3 & $9.0 \mathrm{E}-04$ \\
$\mathrm{NH}_{4} / \mathrm{Mg}-\mathrm{SCBB} / 500$ & $1.0 \mathrm{E}-04$ & $4.0 \mathrm{E}-05$ & 1.000 & 10000.0 & $2.5 \mathrm{E}-04$ \\
$\mathrm{NH}_{4} / \mathrm{Zeolite} / 200$ & $2.0 \mathrm{E}-04$ & $1.0 \mathrm{E}-04$ & 0.998 & 5000.0 & $4.0 \mathrm{E}-04$ \\
$\mathrm{NH}_{4} /$ Zeolite/500 & $1.0 \mathrm{E}-04$ & $1.0 \mathrm{E}-04$ & 0.997 & 10000.0 & $1.0 \mathrm{E}-04$ \\
$\mathrm{NH}_{4} /$ Charcoal/200 & $4.0 \mathrm{E}-04$ & $2.0 \mathrm{E}-04$ & 0.996 & 2500.0 & $8.0 \mathrm{E}-04$ \\
$\mathrm{NH}_{4} / \mathrm{Charcoa} / 500$ & $1.0 \mathrm{E}-04$ & $1.0 \mathrm{E}-04$ & 0.997 & 10000.0 & $1.0 \mathrm{E}-04$ \\
$\mathrm{P} / \mathrm{Mg}-\mathrm{SCBB} / 200$ & $2.0 \mathrm{E}-04$ & $2.0 \mathrm{E}-04$ & 0.991 & 5000.0 & $2.0 \mathrm{E}-04$ \\
$\mathrm{P} / \mathrm{Mg}-\mathrm{SCBB} / 500$ & $1.0 \mathrm{E}-04$ & $2.0 \mathrm{E}-05$ & 0.996 & 10000.0 & $5.0 \mathrm{E}-04$ \\
\hline
\end{tabular}
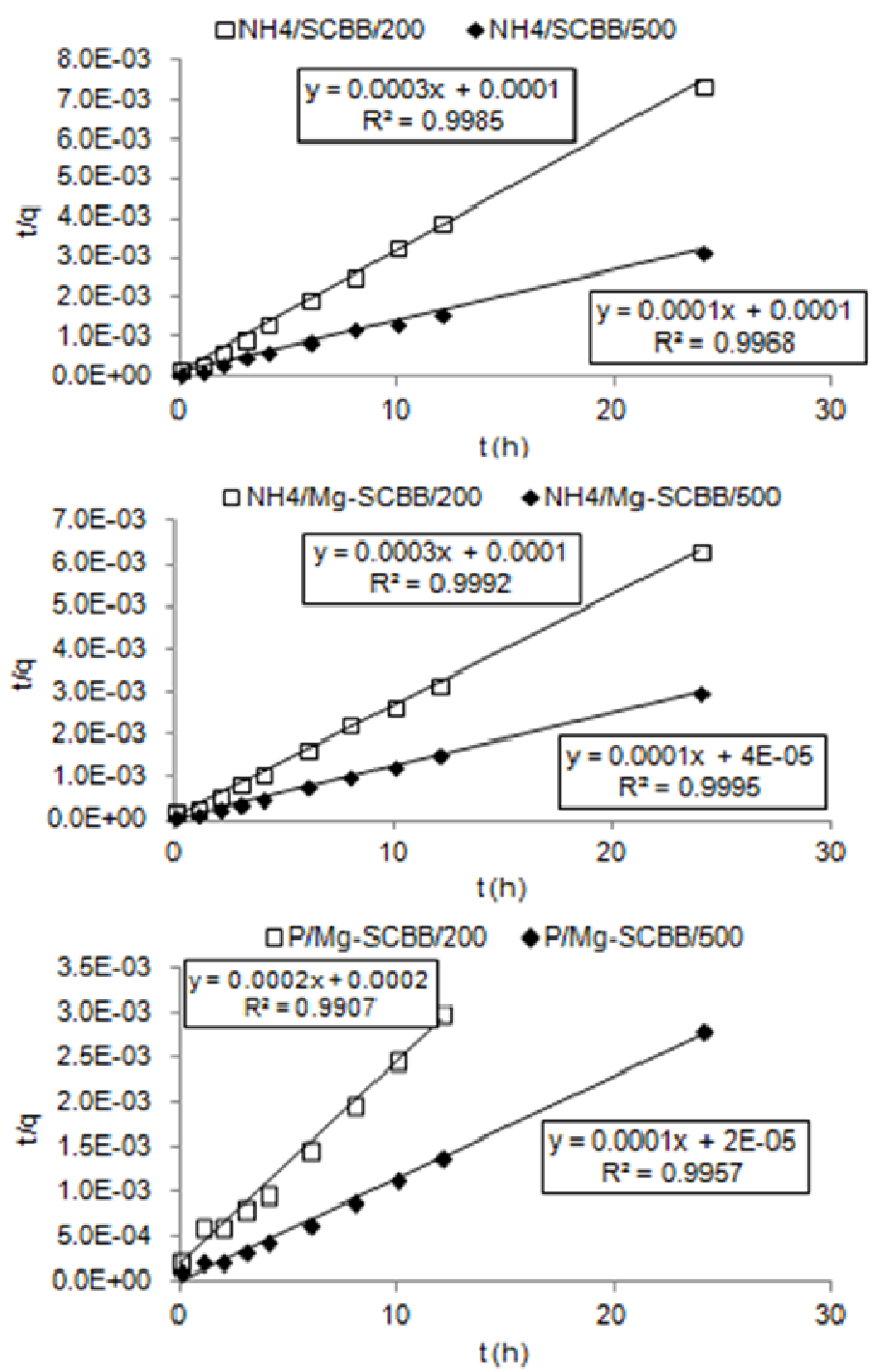

Fig. 8.Fitting data of $\mathrm{NH}_{4}^{+}$and $\mathrm{P}$ adsorption by SCBB and Mg-SCBB to the linear form Eq. 6-1 of the pseudosecond-order kinetic equation 


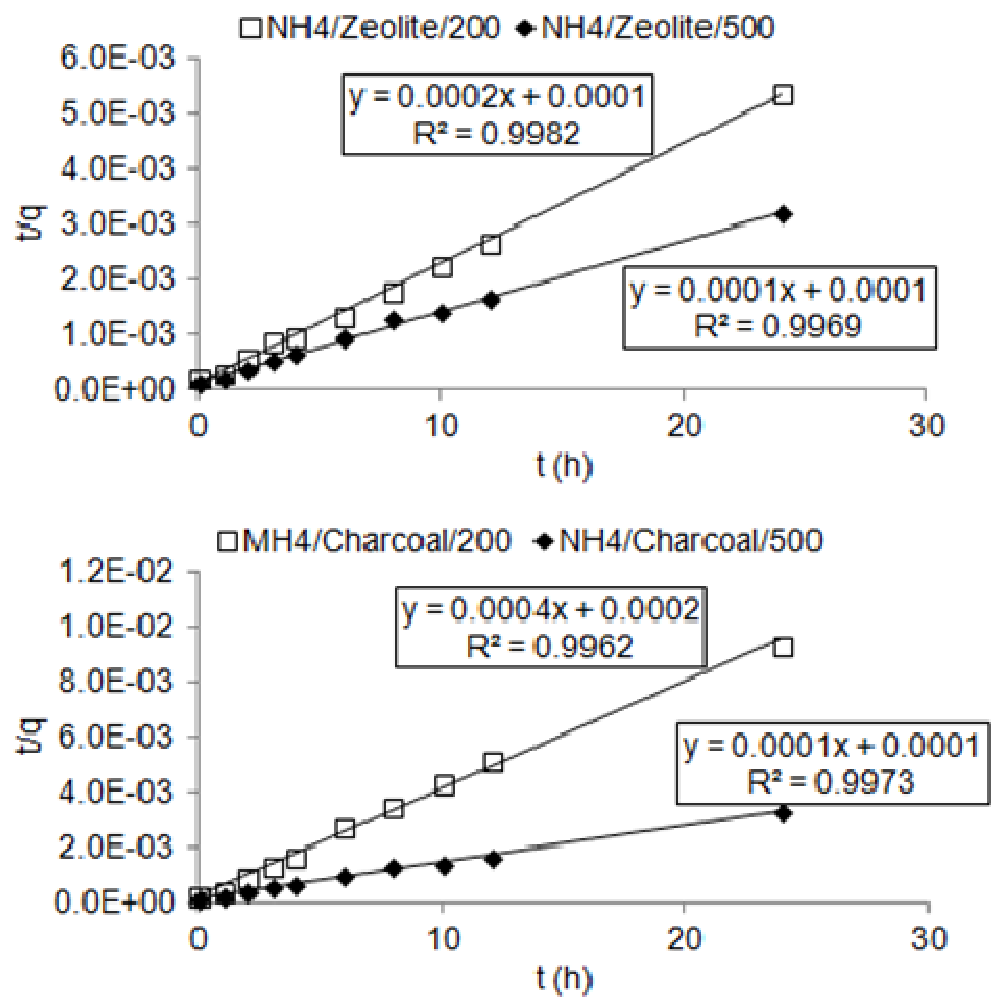

Fig. 9.Fitting data of $\mathrm{NH}_{4}^{+}$and $\mathrm{P}$ adsorption by Zeolite and Charcoal to the linear form Eq. 6-1 of the pseudosecond-order kinetic equation
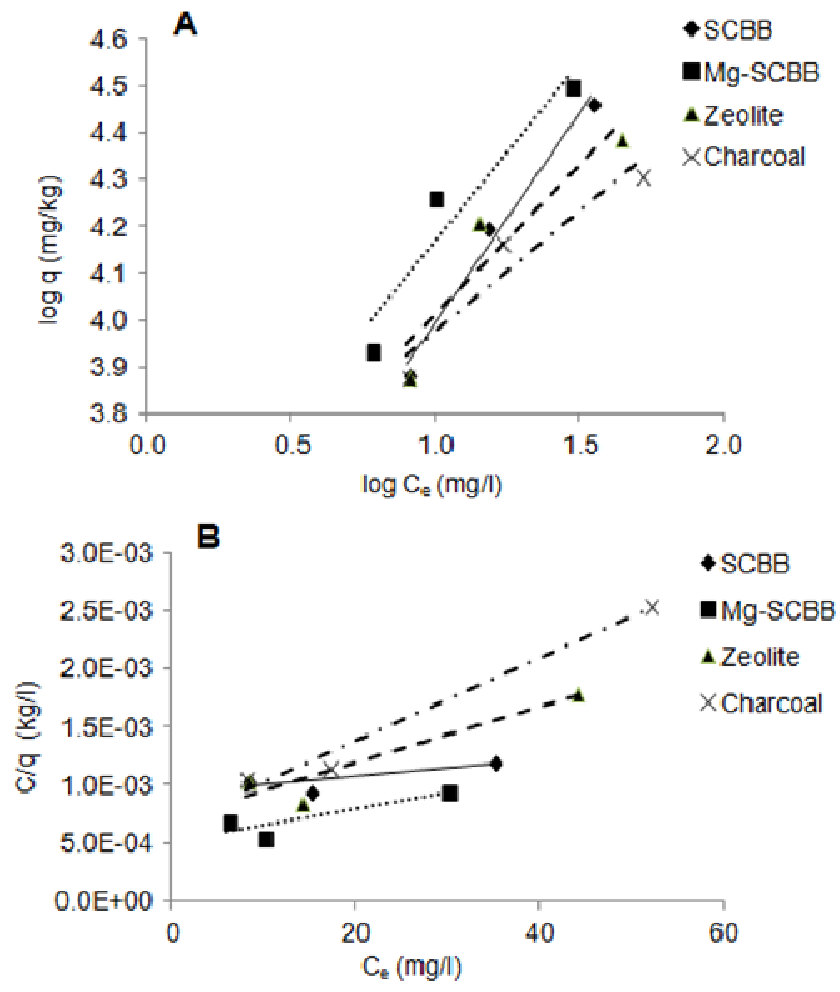

Fig. 10. Fitting data of $\mathrm{NH}_{4}{ }^{+}$adsorption on the tested sorbents to A) Freundlich, and B) Langmuir models 
Table 5. Calculated parameters of Freundlich model from the corresponding linear regressions

\begin{tabular}{lccccc}
\hline Sorbate/sorbent & slope & intercept & $\mathbf{R}^{2}$ & $\mathbf{1} / \mathbf{n}$ & $\mathbf{K}_{\mathbf{f}}$ \\
\hline \multicolumn{5}{c}{ Ammonium } \\
$\mathrm{NH}_{4} / \mathrm{SCBB}$ & 0.895 & 3.099 & 0.982 & 0.894 & 1255.5 \\
$\mathrm{NH}_{4} / \mathrm{Mg}$-SCBB & 0.756 & 3.411 & 0.913 & 0.756 & 2573.9 \\
$\mathrm{NH}_{4} /$ Zeolite & 0.636 & 3.377 & 0.872 & 0.636 & 2379.6 \\
$\mathrm{NH}_{4} /$ Charcoal & 0.510 & 3.465 & 0.911 & 0.510 & 2920.1 \\
\hline \multicolumn{5}{c}{ Phosphate } \\
$\mathrm{P} / \mathrm{Mg}$-SCBB & 0.478 & 3.602 & 0.982 & 0.478 & 4002.2 \\
\hline
\end{tabular}
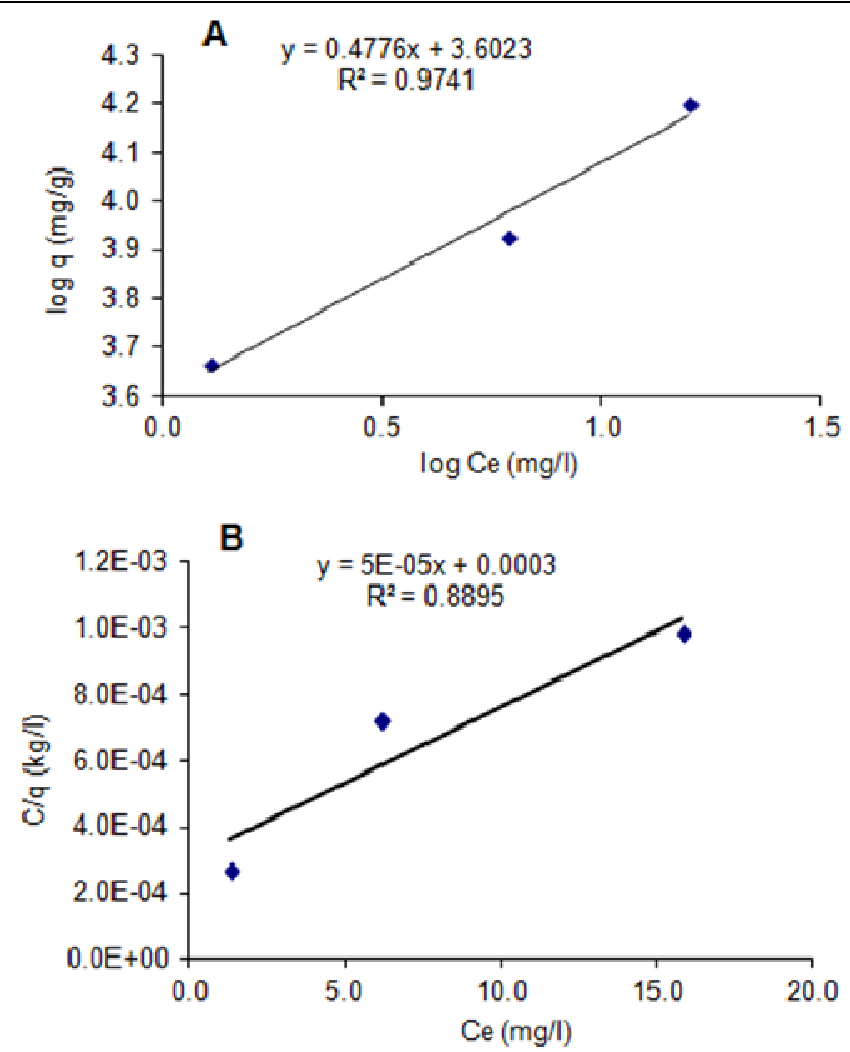

Fig. 11. Fitting data of $P$ adsorption on $\mathrm{Mg}$-SCBB to $\mathrm{A}$ ) Freundlich, and $\mathrm{B}$ ) Langmuir models

Regression parameters of fitting ammonium and phosphate adsorption data are listed in Table (3). Plotting the values of $\mathrm{t} / \mathrm{q}$ vs. $\mathrm{t}$ had the highest determination coefficient $\left(\mathrm{R}^{2}\right)$ of the linear regression plots for all the tested sorbents and ratios (Fig. 8 and 9). Therefore, the linearized form Eq. (6-1) of the pseudosecond-order equation was the best fit. This may suggest the intraparticle diffusion controlled adsorption of ammonium and phosphate on the tested biochars (Ghasemi et al., 2013; Plazinski et al., 2013; Zhang et al., 2015). Parameters of adsorption kinetics ( $\mathrm{q}_{\mathrm{e}}$ and $\mathrm{k}$ ) were then calculated using the obtained slope and intercepts of Eq. (6-1). Generally, the adsorption capacity of ammonium from the aqueous solutions by SCBB and Mg-SCBB were similar and it was higher at 1:500 than at 1:200 (10000 and $3333.3 \mathrm{mg} \mathrm{NH}_{4}^{+} \mathrm{kg}^{-1}$, respectively). The same trend of $\mathrm{q}_{\mathrm{e}}$ was found for phosphate adsorption by $\mathrm{Mg}-\mathrm{SCBB}$ which recorded
5000 and $10000 \mathrm{mg} \mathrm{PO}_{4} \mathrm{~kg}^{-1}$ at 1:200 and 1:500, respectively.

\section{Adsorption isotherms:}

Data of ammonium adsorption by the tested sorbents at different concentrations showed that adsorption of ammonium increases with increasing its initial concentration in the aqueous solution for all sorbents. Fitting these data to different isotherm models revealed that Freundlich isotherm model was the best fit model (highest $\mathrm{R}^{2}$ ) to describe the experimental data (Fig. 10) followed by Langmuir model ( $\mathrm{R}^{2}$ from 0.624 to 871 ). The parameters of Freundlich model were calculated from the regression equations obtained (Table 5). The calculated parameters may indicate that adsorption capacity $\left(\mathrm{K}_{\mathrm{f}}\right)$ of sorbents for ammonium followed the order: Charcoal> Mg-SCBB> Zeolite> SCBB (Table 5). However, the intensity parameter $(1 / n)$ had the range 
from 0.510 to 0.894 and followed the order: SCBB> $\mathrm{Mg}-\mathrm{SCBB}>$ Zeolite> Charcoal. The calculated $\mathrm{n}$ values ranged from 1.96 to 1.12 (between 1 and 10). This may indicate the favorable adsorption of ammonium by the all tested sorbents (Hafshejani et al., 2016).

Isotherms of phosphate adsorption by $\mathrm{Mg}-\mathrm{SCBB}$ (Fig. 11) confirm that adsorption of phosphate on $\mathrm{Mg}$ SCBB was affected by phosphate concentration. These data were better fitted to the Freundlich model than the Langmuir model $\left(\mathrm{R}^{2}: 0.97\right.$ and 0.89 , respectively). The calculated phosphate adsorption capacity and intensity of this sorbent were 4002.2 and $0.478 \mathrm{mg} \mathrm{kg}^{-1}$, respectively. The calculated value of $\mathrm{n}$ (2.09) may indicate the favorable adsorption of phosphate ion on $\mathrm{Mg}$-SCBB. These results are consistent with those obtained by Shwantes et al. (2015). On the other hand, Trazzi et al. (2016) found that Langmuir model gave higher $\mathrm{R}^{2}$ than Freundlich model for adsorption of phosphate ions on sugarcane bagasse biochar.

Accordingly, SCBB and Mg-SCBB biochars proved to have the ability to adsorb ammonium from aqueous solutions compared with the well-known sorbents Zeolite and Charcoal. In addition, Mg-SCBB was the only sorbent capable of removing both ammonium and phosphate from these solutions. Therefore, Mg-SCBB can be used for an efficient dual removal of these two ions from aqueous solutions.

\section{CONCLUSIONS}

Pyrolysis of sugarcane bagasse at $500{ }^{\circ} \mathrm{C}$ under oxygen-limited condition produced a biochar which is capable of efficiently removing ammonium ions from aqueous solutions and it was comparable to commercial Charcoal and Zeolite sorbents. Pre-pyrolysis $\mathrm{MgSO}_{4}$ impregnation of bagasse feedstock produced modified biochar with a dual capability of removing ammonium and phosphate ions from aqueous solutions. Changes in the physical and chemical properties occurred in the generated biochars as compared to the feedstock. Analysis of FTIR bands and SEM investigations revealed that surface chemical functional groups and meso- and micropores were developed due to pyrolysis. Adsorption kinetics data of both ammonium and phosphate ions on the tested sorbents were best described by the linearized form of the second-pseudoorder equation indicating the intraparticle diffusion controlled adsorption of ammonium and phosphate. Ammonium and phosphate adsorption isotherms were best fitted to the Freundlich model and revealed that the adsorption of these ions was favorable by the generated biochars. The Mg-modified sugarcane bagasse biochar can be considered as a promising sorbent for dual removal of ammonium and phosphate ions from aqueous solutions. Further research is needed to investigate the influences of various physical and chemical factors on the efficacy of this biochar in remediating contaminated wastewater.

\section{REFERENCES}

Agegnehu, G., A.K. Srivastavab, and M. I. Bird. 2017.The role of biochar and biochar-compost in improving soil quality and crop performance: A review. Applied Soil Ecol. 119:156-170.

Beesley, L., E. M. Jiménez, and J. L. G. Eyles. 2010. Effects of biochar and green waste compost amendments on mobility, bioavailability, and toxicity of inorganic and organic contaminants in a multi-element polluted soil. Environ. Pollut. 158: 2282-2287.

Bonelli, P. R., M. E. Ramos, E. L. Buonomo, and A. L. Cukierman. 2006. Potentialities of the biochar generated from raw and acid Pre-Treated sugarcane agricultural wastes. 8thAsia-Pacific International Symposium on Combustion and Energy Utilization. October 10-12, 2006, Sochi, Russian Federation.

Cai, R., X. Wang, X. Ji, B. Peng, C. Tan, and X. Huang. 2017. Phosphate reclaim from simulated and real eutrophic water by magnetic biochar derived from water hyacinth. J. Environ. Manage. 187: 212-219.

Carey, D. E., P. J. McNamara, and D. Zitomer. 2015. Biochar from Pyrolysis of Biosolids for Nutrient Adsorption and Turfgrass Cultivation. Water Environ. Res. 87: 20982106.

Carrier, M., A. G. Hardieb, U. Urasa, J. Gorgensa, and J. Knoetze. 2012. Production of char from vacuum pyrolysis of South-African sugar cane bagasse and its characterization as activated carbon and biochar. J. Anal. Appl. Pyrolysis 96: 24-32.

Cha, J. S., S. H. Park, S. Jung, C. Ryu, J. Jeon, M. Shin, and Y. Park. 2016. Production and utilization of biochar: A review. J. Industr. Engineer. Chem. 40: 1-15.

Claoston, N., A. Samsuri, M. A. Husni, and M. M. Amran. 2014. Effects of Pyrolysis Temperature on the Physicochemical Properties of Empty Fruit Bunch and Rice Husk Biochars. Waste Manage. Res. 32: 331-339.

Conley, D.J., H.W. Paerl, R.W. Howarth, D.F. Boesch, S.P. Seitzinger, K.E. Havens, C. Lancelot, and G.E. Likens. 2009. Controlling eutrophication: nitrogen and phosphorus. Sci. 323:1014-1015.

Daffalla, S. B., H. Mukhtar and M. S. Shaharun. 2010. Characterization of Adsorbent Developed from Rice Husk: Effect of Surface Functional Group on Phenol Adsorption. J. Applied Sci. 10: 1060-1067.

De Jesus, J.H.F., G. da C. Cunha, E.M.C. Cardoso, A.S. Mangrich, and L.P.C. Romao. 2017. Evaluation of waste biomasses and their biochars for removal of polycyclic aromatic hydrocarbons. J. Environ. Manage. 200: 186195.

Ding, W., X. Dong, I. M. Ime, B. Gao, and L. Q. Mad. 2014. Pyrolytic temperatures impact lead sorption mechanisms by bagasse biochars. Chemosphere 105: 68-74. 
Dunnivant, F. and E. Anders (eds.). 2006. A basic introduction to pollutant fate and transport. Wiley Interscience, John Wiley, and Sons, Inco., Publication. Hoboken, New Jersey, USA.

El-Gamal, E. H., M. Saleh, I. Elsokkary, M. Rashad, M. M. Abd El-Latif. 2017. Comparison between Properties of Biochar Produced by Traditional and Controlled Pyrolysis.Alex. Sci. Exch. J. 38:412-425.

Fang, Ci, T. Zhang, P. Li, R. Jiang, and Y. Wang. 2014. Application of Magnesium Modified Corn Biochar for Phosphorus Removal and Recovery from Swine Wastewater Int. J. Environ. Res. Public Health 11: 92179237

FAS-USDA, 2017. Egypt, Sugar Annual Report 2017: Egypt's Government Increases the Supply Price for Sugar Cane and Beets Ceding to Farmers' Demands. USDA Foreign Agriculture Service Report. Issued on 18/4/2017.

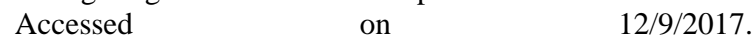
'ȟ-

Gaskin, J. W., C. Steiner, K. Harris, K. C. Das, and B. Bibens. 2008. Effect of Low- Temperature Pyrolysis Conditions on Biochar for Agricultural Use. Am. Soc. Agric. Biol. Engin. 51: 2061-2069.

Ghasemi, N., P. Tamri, A. Khademi, N. S. nezhad, and S. R. W. Alwi. 2013. Linearized equations of pseudo secondorder kinetic for the adsorption of $\mathrm{Pb}$ (II) on Pistacia Atlantica shells. IERI Procedia 5: 232- 237.

Hafshejani, L. D., A. Hooshmand, A. A. Naseri, A. S. Mohammadi, F. Abbasi, and A. Bhatnagar. 2016. Removal of nitrate from aqueous solution by modified sugarcane bagasse biochar. Ecol. Engin. 95:101-111.

Harvey, R. O., B. E. Herbert, L. J. Kuo, P. Louchouarn, 2012. Generalized two-dimensional perturbation correlation infrared spectroscopy reveals mechanisms for the development of surface charge and recalcitrance in plantderived biochars. Environ. Sci. Technol., 46: 1064110650.

Ho, Y.S. 2006. Second-order kinetic model for the sorption of cadmium onto tree fern: A comparison of linear and nonlinear methods. Water Res. 40: 119-125.

Ho, Y.S. and G. McKay. 1999. Pseudo-second order model for sorption processes. Process. Biochem. 34: 451-465.

Huang, Y., P. Chiueh, C. Shih, S. Lo, L. Sun, Y. Zhong, and C. Qiu. 2015. Microwave pyrolysis of rice straw to produce biochar as an adsorbent for $\mathrm{CO}_{2}$ capture. Energy 84: 75-82.

Hugo, T. J. 2010. Pyrolysis of sugarcane bagasse. M. Sc. Thesis. Department of Process Engineering, University of Stellenbosch. South Africa. p 217.

Inyang, M., B. Gao, P. Pullammanappallil, W. Ding, and A. R. Zimmerman. 2010. Biochar from anaerobically digested sugarcane bagasse Bioresour. Technol. 101: 8868-8872.

Jeong C. Y., S. K. Dodla, and J. J. Wang. 2016. Fundamental and molecular composition characteristics of biochars produced from sugarcane and rice crop residues and byproducts. Chemosphere 142: 4-13.

Jiang, Y.P., X.F. Yang, Z.H. Zhang, C.H. Chen, and L.J. Wang. 2013. Progress of the effect of biomass charcoal on soil environment and crop growth. J. Zhejiang Agric. Sci. 25:410-415.

Jindo, K., H. Mizumoto, Y. Sawada, M. A. SanchezMonedero, and T. Sonoki. 2014. Physical and chemical characterization of biochars derived from different agricultural residues. Biogeosciences. 11: 6613-6621.

Kaewprasit, C., E. Hequet, N. Abidi, J. P. Gourlot. 1998. Application of methylene blue adsorption to cotton fiber specific surface area measurement: part I. Methodology. J. Cotton Sci. 2, 164-173.

Keeney, D. R. and D. W. Nelson. 1982. Nitrogen - Inorganic forms. In A. L. Page (ed.), Methods of Soil Analysis, Part 2. pp. 643-698. Am. Soc. Agron., Soil Sci. Soc. Am. Madison, Wis. USA.

Li, H., X. Dong, E. B. da Silva, L. M. de Oliveira, Y. Chen, and L. Q. Ma. 2017. Mechanisms of metal sorption by biochars: Biochar characteristics and modifications Chemosphere 178: 466-478.

Li, J., J. Dai, G. Liu, H. Zhang, Z. Gao, J. Fu, Y. He, and Y. Huang. 2016. Biochar from microwave pyrolysis of biomass: A review. Biomass and Bioenergy 94: 228-244.

Liu, F., J. Zuo, T. Chi, P. Wang, and B. Yang. 2015. Removing phosphorus from aqueous solutions by using iron-modified corn straw biochar. Front. Environ. Sci. Engin. 2015, 9(6): 1066-1075.

Luo, L., C. Xu, Z. Chen, and S. Zhang. 2015. Properties of biomass-derived biochars: Combined effects of operating conditions and biomass types. Bioresour. Technol. 192: 83-89.

Murphy, J. and J. P. Riley. 1962. A modified single solution method for the determination of phosphates in natural waters. Anal. Chem. Acta 27: 31-36.

Noraini, M. N., E. C. Abdullah, R. Othman, and N.M. Mubarak. 2016. Single-route synthesis of magnetic biochar from sugarcane bagasse by microwave-assisted pyrolysis. Materials Letters 184: 315-319.

Pan, G.X., A.F. Zhang, and J.W. Zou. 2010. Biochar from agro-byproducts used as an amendment to croplands: an option for low carbon agriculture. J. Ecol. Rural Environ. 26: $394-400$.

Plazinski, W., J. Dziuba, and W. Rudzinski. 2013. Modeling of sorption kinetics: the pseudo-second-order equation and the sorbate intraparticle diffusivity. Adsorption 19:10551064.

Qiu, Y., Z. Zheng, Z. Zhou, and G.D. Sheng. 2009. Effectiveness and mechanisms of dye adsorption on a straw-based biochar. Bioresour. Technol. 100: 5348-5351.

Saleh, M. E., A. A. El-Refaey and A. H. Mahmoud. 2016. Effectiveness of Sunflower Seed Husk Biochar for Removing Copper Ions from Wastewater: a Comparative Study. Soil Water Res. 11: 53-63. 
Saleh, M. E., A. H. Mahmoud and M. Rashad. 2012. Peanut Biochar as a Stable Adsorbent for Removing NH4-N from Wastewater: A Preliminary Study. Advances in Environ. Biol. 6: 2170-2176.

Saleh, M. E., A. H. Mahmoud, and M. Rashad. 2013. Biochar Usage as a cost-effective bio-sorbent for removing $\mathrm{NH}_{4}-\mathrm{N}$ from wastewater. The international conference the Global Climate Change, Biodiversity and Sustainability: Challenges and Opportunities in Arab MENA region and EuroMed. 15-18 April 2013 Alexandria, Egypt.

Samsuri A.W., F. Sadegh-Zadeh, and B. J. Seh-Bardan. 2014. Characterization of biochars produced from oil palm and rice husks and their adsorption capacities for heavy metals. Int. J. Environ. Sci. Technol. 11: 967-976.

Schwantes. D., A. C. Gonçalves Jr., D. C. Schons, T. G. Veiga, R. C. Diel, and V. Schwantes. 2015. Nitrate Adsorption using Sugar Cane Bagasse Physicochemically Changed. J. Agric. Environ. Sci. 4: 51-59.

Sizmur T., T. Fresno, G. Akgül, H. Frost, and E. MorenoJiménez. 2017. Biochar modification to enhance sorption of inorganics from water. Bioresour. Technol. (in press)

Strock, J., A. Ranaivoson, G. Feyereisen, K. Spokas, D. Mulla, and M. Roser. 2017. Nutrient removal in agricultural drainage ditches. Final Report for State of Minnesota Project Contract \#63906, p 99.

Takaya, C. A., L. A. Fletcher, S. Singh, U.C. Okwuosa, and A. B. Ross. 2016. Recovery of phosphate with chemically modified biochars. J. Environ. Chem. Engineer. 4:11561165.

Tan, Z., C. S. K. Lin, X. Ji, and T. J. Rainey. 2017. Returning biochar to fields: A review. Applied Soil Ecol. 116:1-11.

Teixid?, M., J. J. Pignatello, J. L. Beltr?n, M. Granados, and J. Peccia. 2011. Speciation of the ionizable antibiotic sulfamethazine on black carbon (biochar). Environ. Sci. Technol. 45:10020-27.
Trazzi, P. A., J. J. Leahy, M. H. B. Hayes, and W. Kwapinski. 2016. Adsorption and desorption of phosphate on biochars. J. Environ. Chem. Engin. 4: 37-46.

Ulyett, J., R. Sakrabani, M. Kibblewhite, and M. Hann. 2014. Impact of biochar addition on water retention, nitrification and carbon dioxide evolution from two sandy loam soils. Europ. J. Soil Sci. 65:96-104.

Weber, W., and J. Morris. 1963. Kinetics of adsorption on carbon from solution. J. Sanit. Eng. Div. Am. Soc. Civ. Eng. 89: 31-60.

WHO. 2017. Don't pollute my future! The impact of the environment on children's health. World Health Organization. Geneva, License: CC BY-NC-SA 3.0 IGO. 130.

Xu, R.K., S.C. Xiao, J.H. Yuan, and A.Z. Zhao. 2011. Adsorption of methyl violet from aqueous solutions by the biochar derived from crop residues. Bioresour. Technol. 102: 10293-298.

Yao, Y., B. Gao, J. Chen, M. Zhang, M. Inyang, Y. Li, A. Alva, L. Yang. 2013. Engineered carbon (biochar) prepared by direct pyrolysis of $\mathrm{Mg}$-accumulated tomato tissues: characterization and phosphate removal potential. Bioresour. Technol. 138: 8-13.

Zhang, L., H. A. Lo?iciga, M. Xu, C. Du and Y. Du. 2015. Kinetics and Mechanisms of Phosphorus Adsorption in Soils from Diverse Ecological Zones in the Source Area of a Drinking-Water Reservoir Int. J. Environ. Res. Public Health 12: 14312-14326

Zhang, Z.H., Z.H. Lin, and Y.Q. Fu. 2010. The state of applications of biochar in agriculture. J. Anhui Agric. Sci. 38:11880-11882.

Zheng, W., M. Guo, T. Chow, D.N. Bennett, and N. Rajagopalan. 2010. Sorption properties of greenwaste biochar for two triazine pesticides. J. Hazard. Mater. 181: $121-126$ 


\section{الملخص العربي}

استخدام مخلفات عصر قصب السكر المعللة بالمغنسيوم في الإزالة المزدوجة لأيونات الأمونيوم

\section{و الفوسفات من المحاليل المائية}

ماهر السيد صالح ، رمزي مرسي رزق هـدية

على إز الة أيونات الفوسفات من المحاليل المائيــة. وكـــان

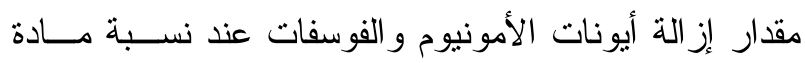

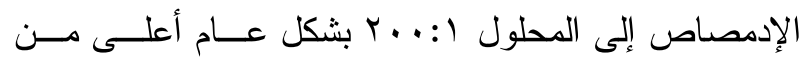
النسبة ا: . .0 عند نفس التركيزات. وقد ثبت حدوث تطاير الإهـ

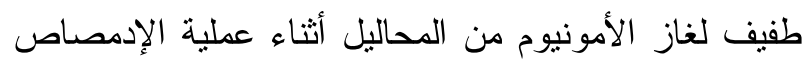

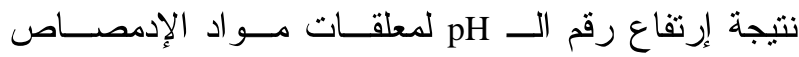

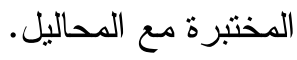
ووجد أن نتائج حركية إدمصاص Adsorption Kinetics

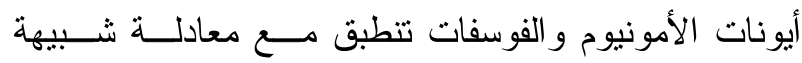

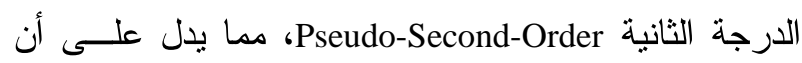

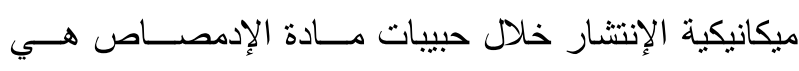
الخطوة المتحكمة في عملية الإدمصاص. كما ثبت أن نتائج

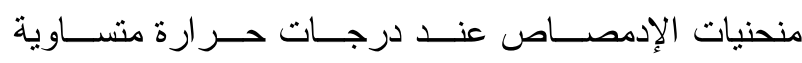
Adsorption Isotherms فرويندليخ الرياضي Freundlich Model. وكانت قيم معامل

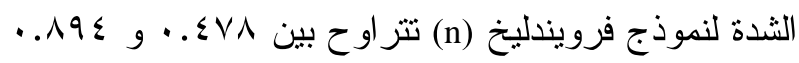

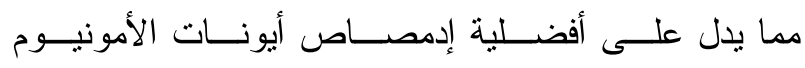
و الفوسفات بو سطة مو اد الإدمصاص المختبرة. وكانت سعة لإنة

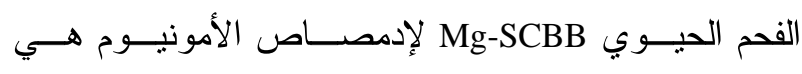
9 . roVr. 9 ويمكن القول بأن الفحم الحيوي المنتج من مصاصة القصب المخصبة بكبريتات المغنسيوم (Mg-SCBB) يمكن أن يمنل مادن

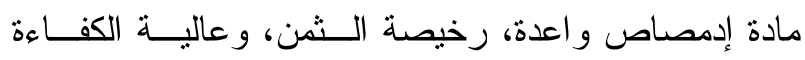

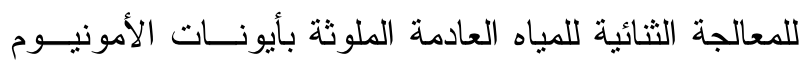
و الفوسفات.

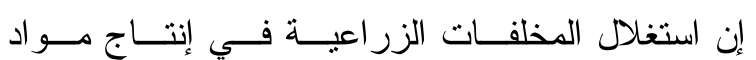

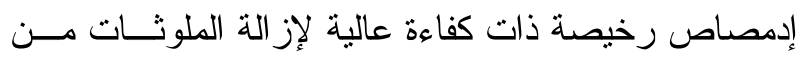
المياه العادمة يعتبر من التحديات البيئية المعاصــرة. وفــي لإزهي

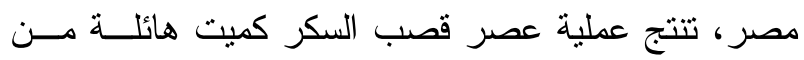
مصاصة قصب السكر (SCBF) بكميات هائلة كمو اد عادمة. وتهدف هذه الدراسة إلى بحث تأثير التعديل الكيميائي على لى هيل خو اص الفحم الحيوي لمصاصة قصب السكر، وتثقيم كفاءة هذا الفحم في إز الة كل من أيونات الأمونيوم و الفوسفات من ون ولي المحاليل المائية الإصطناعية. ثم إنتاج فحم مصاصة القصب الخـام (SCBB) وفحــ مصاصة القصب المعدلة بالمغنسيوم (Mg-SCBB) بطريقـــة

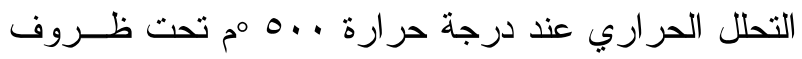
محدودة من الأوكسجين لـصاصة القصب الخام و الدخصبة

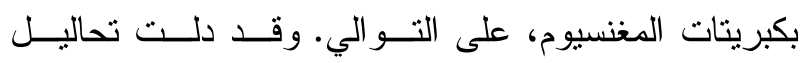

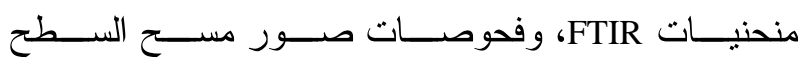
بالميكروسكوب الإككتروني SEM، وكذلك بعض الخـــواص الفزيائية و الكيميائية لنوعي الفحم الناتجين على ظهور ولإكتروني العديد من المجاميع الكيميائية السطحية، وتكوين المسام المتوسطة

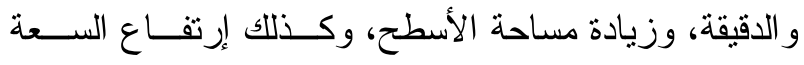
التبادلية الكاتيونية بالمقارنة بالمادة الأولية (SCBF). وقد أظهر ا نوعي الفحم SCBB, Mg-SCBB اللذان تـــ إنتاجها ميو لا عالية وقدرة على إمتصاص أيون الأمونيوم

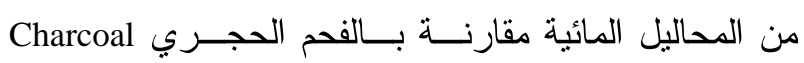
و الزيو لايت Zeolite. كما وجد أن الفحم Mg-SCBB (الناتج من تخصيب مصاصة القصب بالمغنسيوم) هو الوحيد القادر 